\title{
When the US far-right sneezes, the European far-right catches a cold. Quasi-experimental evidence of electoral contagion from Spain.
}

\author{
Stuart J. Turnbull-Dugarte*
}

\author{
José Rama ${ }^{\ddagger}$
}

V2.1 (June 2021)

\begin{abstract}
Does the electoral defeat of a far-right party abroad influence support for similar parties at home? By exploiting the quasi-experimental setting provided by the coincidental timing of Donald Trump's 2020 electoral defeat with the Spanish Sociological Study's monthly barometer data collection, we provide robust causal evidence to show that Trump's electoral loss in the US had a negative contagious spillover effect on self-reported support for the Spanish far-right. Empirically we estimate treatment effects based on the as good as random exposure to the electoral results, as well as regression discontinuity models to isolate the causal impact of Trump's defeat on the voting intentions for Spain's new far-right party, VOX. Our results - which are robust to various modelling approaches including covariate adjustment, regional fixed effects, placebo issues and nearest-neighbour matching demonstrate that Trump's defeat to Joe Biden had a sizeable negative effect on support for VOX. The contagion effect is substantive: equal to 3-5 percentage-points among the general population and 8-11 percentage-points among right-wing voters. Our findings make an important contribution to the broader literature on electoral behaviour as they indicate that the electoral success of ideologically symmetrical parties abroad can play a role in understanding a party's domestic success.
\end{abstract}

Keywords: contagion effects, electoral spillovers, far-right, quasi-experiment, Spain, Trump, VOX

\footnotetext{
${ }^{*}$ University of Southampton. Email: S.Turnbull-Dugarte[at]soton.ac.uk

${ }^{+}$Universidad Autonoma de Madrid. Email: Jose.Rama[at]uam.es

$\ddagger$ We are very grateful to Daniel Devine, Joshua Townsley and Erik Gahner Larsen for their feedback on earlier iterations of this paper.
} 


\section{Introduction}

When Donald Trump surprisingly won the US presidency in 2016, political commentators were quick to point to the far-right's accession to the White House as a troubling sign of the global expansion of radical right-wing populism and the rise of an increasingly electorally successful far-right. Not only was the transnational far-right movement (Kuyper \& Moffit, 2019; Moffit, 2017; Van Hauwaert, 2019) gifted a friend in power, but Trump's success also served as a mobilising victory against which the far-right parties of Europe could rally their supporters around, what Mudde (2016) penned, a "narrative of hope". Trump's victory in 2016, was followed in 2017 by a string of the successes for far-right parties in Europe: with a 3-point growth in the vote share for Partij voor de Vrijheid (PVV) in the Netherlands; 3.4-points for France's Front National (FN) ${ }^{1} ; 7.9$ for Alternative für Deutschland (AfD), and 5.4 for Freiheitliche Partei Österreichs (FPO) relative to their previous electoral results.

Four years of the Trump presidency resulted in the far-right leader being ousted from office after only one term, in part due to his mismanagement of the Covid-19 pandemic (Neundorf \& Pardos-Prado, 2020), with Trump becoming only the fifth president in US history whose time in office was limited to a single term. Pundits reacted quickly to Trump's loss, speculating that his fall would signal the retreat of the far-right. Whilst we are critical of such speculation, particularly given the consistent polling performance of these parties throughout the Covid-19 pandemic (Wondreys \& Mudde, 2020), we argue that understanding the potential spillover effects of the US far-right's demise represents an important empirical question that merits investigation. Existing work provides strong causal evidence that Trump's 2016 success triggered a rise in racist contagion abroad (Giani \& Meón, 2019). Given the electoral support for far-right movements is, in part, motivated by anti-immigrant attitudes (Halikiopoulou \& Vlandas, 2020), the success of a candidate promoting explicit racist campaign rhetoric formed part of the the "narrative of hope" enjoyed by the far-right at the time (Mudde, 2016).

\footnotetext{
${ }^{1}$ Renamed Rassemblement national as part of a 2018 rebranding strategy.
} 
If Trump's success can fuel the flames of support for parties that advocate comparable positions by increasing the social tolerance of their signature policy issues (Giani \& Meón, 2019), does the widely reported and global news story of his defeat influence support for the comparable parties cross-nationally? In short: if the US far-right sneezes, does the far-right abroad catch a cold?

To assess the causal impact of the electoral defeat of Donald Trump on far-right party success, we exploit the quasi-experimental setting produced by the coincidental timing of the US election and the fieldwork for the Spanish Sociological Research Centre's (Centro de Investigaciones Sociológicas - CIS) monthly barometer in November 2020. Relying on the naturally exogenous exposure to electoral defeat among a sample of 3,830 respondents, we argue that far-right party defeats abroad can signal right-wing voters to question the viability and desirability of similar parties and candidates at home.

Empirically, we demonstrate that the (naturally occurring) treatment assignment afforded by the quasi-experimental setting in Spain led to a significant fall in self-reported voting intentions for the Spanish populist radical right-wing party, VOX. Those respondents interviewed immediately after the US election result was announced were between 3-5 percentage-points less likely to support VOX in when compared to those interviewed immediately before. The average contagion effect of Trump's loss is even greater amongst those of the right - i.e. those most inclined to express their intention to vote for VOX - when exposed to treatment. Our results - which are robust to various modelling approaches including covariate adjustment, regional fixed effects, placebo issues and nearest-neighbour matching - demonstrate that negative electoral spillover can influence, at least in the short-term, the potential success radical right-wing parties are able to enjoy.

This article reinforces the idea of an international or transnational populist far-right movement (Moffit, 2017) that is not limited to the confines of national borders (Rydgren, 2005; Van Hauwaert, 2019). Not only is there an observable connection between Trump and VOX on the supply side (parties) - evinced by the rhetoric and ideological 
symmetry between the two parties positions and the established networks between the two (Rama et al., 2021, pp.59-63) - but the results presented here suggest there is a also a link on the demand side (voters). The presence of a far-right populist "movement" is clear (Kuyper \& Moffit, 2019), and our findings demonstrate that the losses of different branches of the "movement" across the confines of state boundaries can signal voters regarding both the undesirability and limited viability of these parties at home. Similarly to the arguments presented by Bischof and Wagner (2019), who argue that far-right success can legitimise the concerns - like anti-immigrant sentiment (Giani \& Meón, 2019) - of those with the potential to support far-right parties, we argue that the electoral defeat of these same parties can have a symmetrical (negative) effect on their potential support. Van Hauwaert (2019) theorises that the development of the contemporary far-right in individual countries is not independent but rather the product of increasingly transnational and interdependent diffusion of both demand and supply side factors. Our empirical findings support on the demand of this thesis.

In addition to contributing new empirical findings that expand our knowledge related to the cross-national contagion effects of political outcomes, our contribution also provides an insight into the determinants of (short-term) far-right success. Far-right victories can drive political polarisation (Bischof \& Wagner, 2019) and has been observed to significantly increase reported hate crimes (Devine, 2021; Edwards \& Rushin, 2018). Similarly, the electoral threat presented by far-right gains can further drive the "mainstreaming" of their issue priorities (Mudde, 2019). The electoral victories of radical right-wing parties can cause party contagion of the anti-immigrant issues they often advocate among mainstream parties $^{2}$ (Abou-Chadi, 2016; Abou-Chadi \& Werner, 2020). The long-term influence of their success, therefore, presents a significant threat to liberal democratic values (Rama \& Casal Bértoa, 2020) and, given their

\footnotetext{
${ }^{2}$ The empirical evidence suggests, however, that those parties who engage in such accommodating copy-cat behaviour are actually electorally punished. Abou-Chadi and Wagner (2020), for example, show that social democratic parties' adoption of eurosceptic and anti-immigrant positions is associated with reduced vote shares for these parties. Similarly, Krause et al. (2019) show that mainstream parties that adopt an accommodating response to far-right parties' positions can lead to net gains for the radical right.
} 
anti-immigrant and socially conservative (heteronormative) values, their mainstreaming effect is likely to be inimical to the welfare of minority groups such as non-white individuals or LGBT+ citizens. We view understanding what drives (and limits) the far-right as imperative given the substantive, and often negative, impact of far-right success on political and societal behaviour.

\section{Expectations}

An expanding body of literature highlights the causal effect of concrete and salient political events on electoral outcomes and political preferences. Devine (2021), for example, empirically demonstrates that the outcome of the UK's Brexit referendum led to a sizable increase in (reported) religious and racially motivated hate crimes. Testing the causal impact of Trump's victory in 2016, Edwards and Rushin (2018) find a rise in hate-crimes in the US. The theorised mechanism behind these observed spikes in discriminatory behaviour is that these events validated and legitimised "the underlying [nativist] prejudices enough to lead to public expressions of this prejudice" (Devine, 2021, p.383).

Comparable behavioural and attitude-shaping effects are observed across a number of different countries and settings. A wealth of literature, for example, highlights the causal impact of terrorist attacks on attitudes towards immigration (Ferrín et al., 2020) ${ }^{3}$ as well as electoral choices (Aytac \& Carkoglu, 2019; Montalvo, 2011). To give but one illustrative example, quasi-experimental evidence of Al Queda's 2004 terrorist attack in Madrid's Atocha train station, demonstrates that the attack had a significant effect on the election that took place a few days afterwards (Montalvo, 2011). Other domestic shocks, such as court decisions (Bridgman et al., 2020), natural disasters (Chang \& Berdiev, 2015), corruption scandals (Ares \& Hernández, 2017), and shifts in exposure to refugees (Dinas et al., 2019) are all identified as significant "watershed" events that

\footnotetext{
${ }^{3}$ See, however, Giani (2020) who argues that terrorist attacks increase perceived security risks but $d o$ not increase out-group prejudice.
} 
trigger individual citizens to update their preferences and political behaviours.

Importantly, the effect of political and societal shocks also have an impact beyond the confines of the state boundaries. Delis et al. (2020), for example, relying on a quasiexperimental research design, demonstrate that the unexpected outcome of the UK's Brexit referendum, which triggered the process of the UK's exit from the European Union (EU), had a significant impact on electoral choices in Spain. Comparing those who cast their ballots before the Brexit result was announced to those who cast their ballots immediately afterwards, the authors argue that the signals of political and economic instability brought about by the Brexit results - as illustrated by the volatility in the international stock market - led a substantive fall in support for anti-system parties.

Beyond the electoral arena, there is also evidence of far-right development exhibiting, not only a local influence (Newman et al., 2020), but also cross-national influences on public opinion. Analysing the causal effect of Donald Trump's 2016 electoral victory, via a quasi-experimental design, Giani and Meón (2019) demonstrate that the Trump victory significantly increased self-reported racial biases in European states. Theoretically, and in line with the legitimising mechanisms argued to be driving the Trump and Brexit-based rise in reported hate crimes (Devine, 2021; Edwards \& Rushin, 2018), Giani and Meón (2019) argue that the identified effect of Trump's 2016 election victory on cross-national racist biases is the result of Trump's success signalling that nativist and anti-immigrant prejudices have become more mainstream and, as a result, revealing these preferences in surveys is no longer as constrained by concerns over social acceptability.

Whilst Giani and Meón (2019)'s findings might suggest that the 2016 Trump victory could further fan the flames of the European far-right, other empirical contributions suggests that it may have increased resilience against the rise of the anti-globalist nationalism these parties tend to advocate. Minkus et al. (2019), for example, present causal evidence demonstrating that Trump's 2016 success also brought about a rise in 
support for European integration, a liberal and pro-globalist policy dimensions that is often negatively correlated with far-right support (Santana et al., 2020; Vasilopoulou, 2018). The "rally around the EU" effect observed is, according to the authors, the result of citizens perceiving domestic liberal norms as being under threat from an external actor. ${ }^{4}$ Presenting a similar theoretical model, Turnbull-Dugarte (2021), shows that the rise of liberal norms abroad - illustrated by advances in LGBT+ rights - can also trigger a rejection of these norms amongst citizens in states that view these international norm changes as inimical to their own domestic value systems.

Given studies evince the role of cross-national spillover effects on preferences and attitudes (Giani \& Meón, 2019; Minkus et al., 2019; Turnbull-Dugarte, 2021), as well as electoral behaviour (Delis et al., 2020), we seek to assess the impact of Donald Trump's electoral defeat in a cross-national setting.

The research question we seek to answer is straightforward: did the electoral defeat of Donald Trump and the US far-right influence support for the far-right in Spain? Given the data availability, however, we limit the scope of our research question to focus on self-reported expressions of support for the far-right. Theoretically, the literature focused on the effect of far-right largely points to their success exhibiting a legitimising effect (Bischof \& Wagner, 2019; Valentim, 2021). When far-right candidates like Trump or far-right issues like Brexit are successful, individuals who are sympathetic with the winning issues are likely to view their preferences as validated and legitimised by their success (Bicchieri, 2016; Devine, 2021; Tankard \& Palcuk, 2016). This, in turn, leads these voters to increase their willingness to disclose discriminatory preferences (Giani \& Meón, 2019); become more comfortable reporting their support for far-right parties (Valentim, 2021); and may also encourage them to act out on their radical beliefs by engaging in discriminatory (and often criminal) behaviour (Devine, 2021; Edwards

\footnotetext{
${ }^{4}$ Internal threats can also trigger backlash. Relying on observational data, Turnbull-Dugarte (2020) argues that there is a correlation between the rise of the Alternative für Deutschland (AfD) and a spike in europhile positions among mainstream parties in Germany and amongst their voters. This suggests that when the EU is presented with a far-right threat, euro-pragmatists are more likely to come out in defend the EU from the challenger.
} 
\& Rushin, 2018). Just as Bischof and Wagner (2019) argue that far-right success can embolden further far-right support, we present a theoretically symmetrical argument that posits that far-right losses can undermine self-expressed far-right support and that these effects are not restricted by state boundaries. We hypothesise that the electoral defeat of an emblematic leader of the transnational far-right movement like Trump (Mudde, 2016, 2017; Norris, 2020) can trigger a contagious reduction in support for the far-right cross-nationally. Electoral defeat is likely to serve as a heuristic of the potential viability and likely success of these parties that triggers voters to update their prior levels of support for radical right-wing challengers.

H1 (legitimacy thesis): The electoral defeat of a far-right party abroad will reduce support for the far-right at home.

Theoretically, however, we might expect to observe the reverse relationship. The legitimacy thesis assumes that individuals take the the victory and defeat of far-right parties as indicative signals of the level of public support for these parties and the policies they advocate. This mechanism is based on the expectation that individuals update their self-reported expressions of party support in a direction that is congruent with the signal received from the party's electoral fortunes: a victory for the party will increase the propensity to express support whilst a failure for the party will decrease the likelihood of expressing support. An alternative reaction, however, could be that voters respond in opposition to the public signals of support in a form of retributory backlash. In this setting, we might expect individuals sympathetic towards the farright in Spain to be mobilised by what they view as an unjust defeat that, fermented by conspiracy theories regarding election fraud, galvanises them to increase their sympathies for the far-right party and its leader. This expectation is congruent with evidence that voters can be mobilised to "rally around" the issues and parties they support when they view them as being under threat (Minkus et al., 2019; Turnbull-Dugarte, 2020).

H2 (backlash thesis): The electoral defeat of a far-right party abroad will increase support 
for the far-right at home.

There is reason to expect that the effects of Trump's loss, regardless of their direction, are unlikely to be symmetrical for different voting constituencies in the electoral. Farright parties often tend to source their voter revenue from those political parties that are spatially closest to them (Rydgren, 2007). ${ }^{5}$ As a result, and as is shown in the case of far-right parties in general but also in the case of VOX (Rama et al., 2021), the electorate of these parties tend to come from the portion of voters who identify with the right. Individuals who identify on the left are very unlikely to vote for far-right parties at all so any legitimising or backlash effect of far-right party performance abroad is not likely to exhibit any persuasive influence over their self-reported support for these parties.

H3 (conditional thesis): The effects of far-right electoral fortunes abroad will be greatest among voters who identify on the right.

\section{Case selection, Trump \& the Spanish far-right}

\subsection{Trump's Republican Party: far-right?}

We argue, very much in agreement with the existing literature (Mudde, 2017, 2019), that Trump, as a radical right-wing populist and authoritarian nationalist (Norris, 2020; Norris \& Inglehart, 2019), falls neatly within the far-right party typology. Indeed, Mudde (2017) argues that the rise of Donald Trump to the presidency on the back of a conventional party ticket is illustrative of what he pens the "mainstreaming" of the far-right that has taken hold democratic states following the turn of the century (Mudde, 2019) and, more recently, following the financial crisis of 2008. Trumpism which combines of anti-immigrant nativism, socially conservative authoritarianism,

\footnotetext{
${ }^{5}$ This explains, in part, why mainstream right-wing parties have reacted to accommodate the policy positions advocated by radical right-wing challenger parties (Abou-Chadi \& Stoetzer, 2020).
} 
and populist anti-establishment sentiment - is very similar to the core ideology toolkit of the European populist radical right (Mudde, 2017, p.48). Descriptive data from the Global Party Expert Survey (Norris, 2020) supports the argument that there is crossnational symmetry between the ideological positions advocated by the Republicans (under Trump) and those parties that are well-established as constituents of the populist radical right. In Figure 1 we illustrate that the Trump's Republican party falls nearly within the the hard-line socially conservative right-wing authoritarian space that VOX, and a battery of other European far-right parties, inhabit. We therefore maintain, congruent with Norris (2020, p.245) that Trump's transformation of the GOP into an authoritarian populist party makes it a prime example of the wider family of far-right parties.

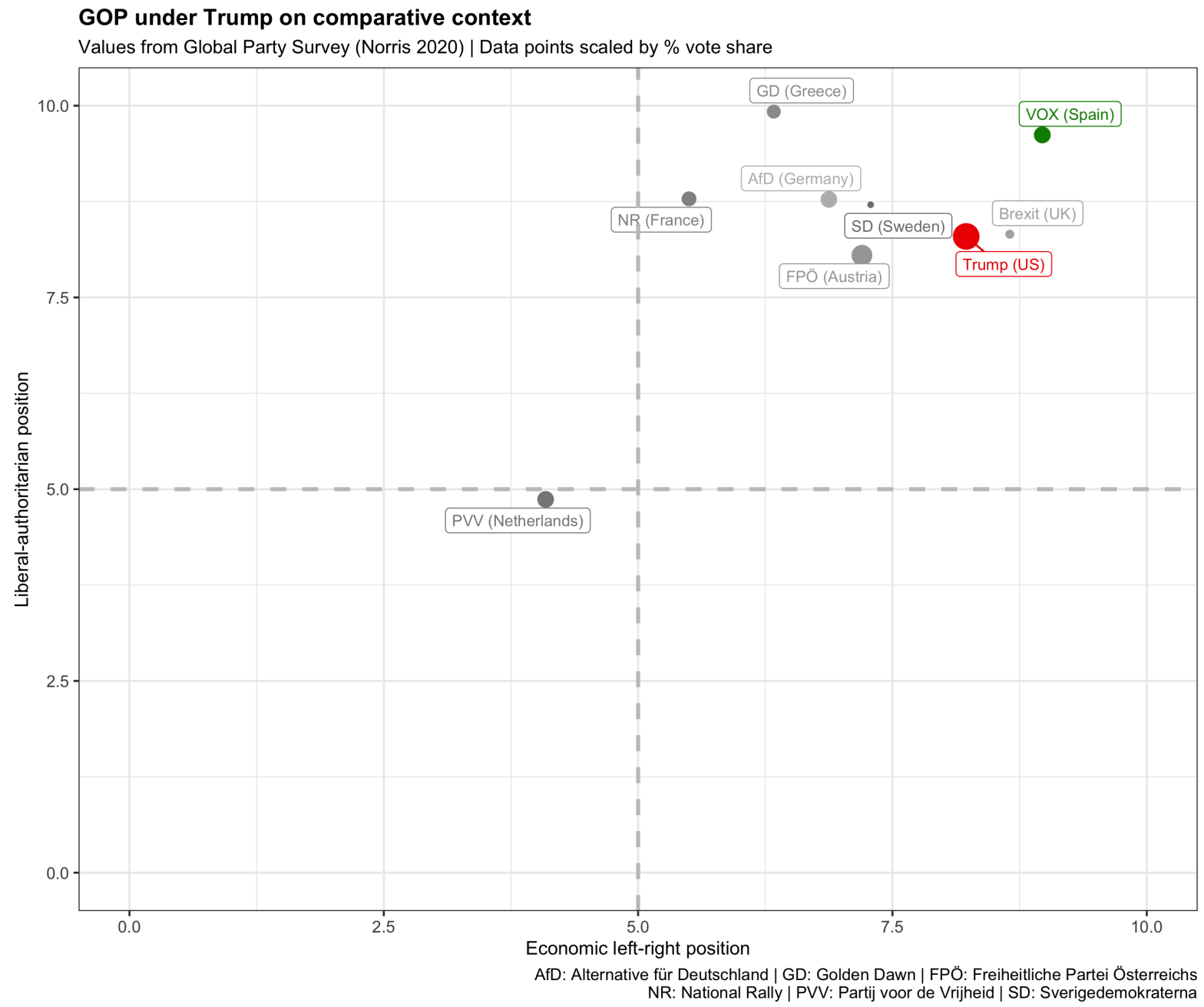

Figure 1: Trump's Republican Party in contemporary far-right space 


\subsection{The far-right in Spain: a most likely case}

The selection of Spain as a case study is a product of the data availability providing us with a quasi-experimental setting which lends itself to causal identification. We argue, however, that Spain represents an ideal case to test our theoretical expectations.

A relatively new party in Spain, VOX brought to an end Spain's former "exceptional status" as a country free from the radical right by relying on a combination of antiimmigrant discourse (Mendes \& Dennison, 2021) and monopolising the issue of Catalan seperatism (Turnbull-Dugarte, 2019). Like other far-right parties that have conventionally engaged in the contagious diffusion of far-right rhetorical tools (Rydgren, 2005; Van Hauwaert, 2019), Spain's new populist radical right-wing party, VOX, has very much sought, to mirror Trumpian messages in it's communication strategy (Rama et al., 2021). Their debut campaign slogan promised to "Make Spain Great Again" [Hacer España Grande Otra Vez] and called for "Spain First" [España lo primero] in what were clear examples of the party's attempt to directly plagiarise Trump's campaign rhetoric. The connection between VOX and Trump, however, goes beyond rhetoric and includes the establishment of networks with transnational organisations and likeminded hard-line conservative think-tanks. In 2020, leaders of the Spanish far-right were in attendance at the Conservative Political Action Conference (CPAC) at the expense of the American Conservative Union Foundation, and ex-Trump strategists and allies, including Steven Bannon, have formed close links with VOX's leadership and communications team (Cervilla, 2020).

VOX's close ties with the US far-right, and the party's vocal admiration of the Trump administration - which includes sponsoring a resolution in the European Parliament nominating Trump's candidacy for the Nobel Peace Prize ${ }^{6}$, has also translated to higher

\footnotetext{
${ }^{6}$ See: https:/ /www.europarl.europa.eu/doceo/document/B-9-2020-0256_ES.html
} 


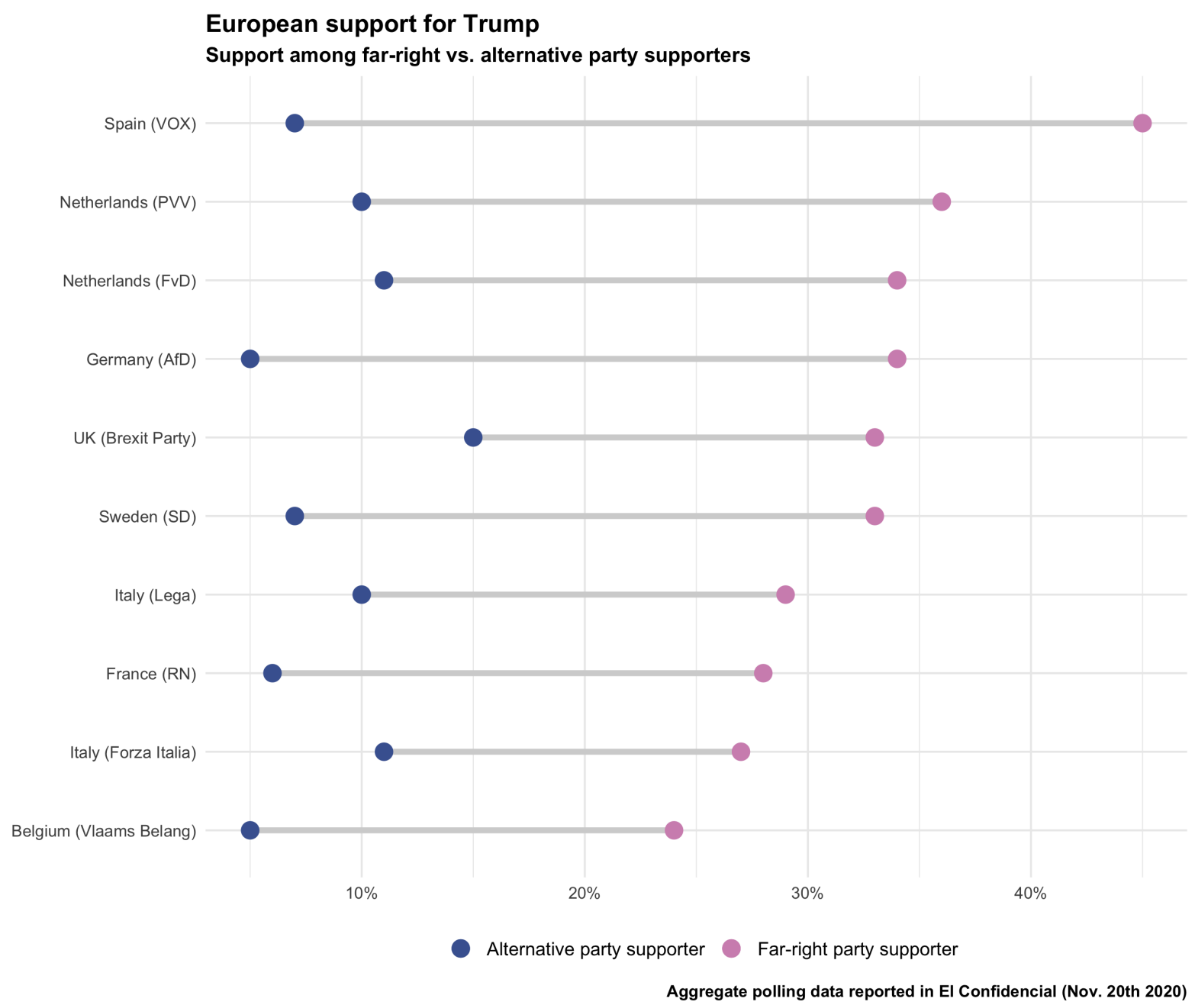

Figure 2: VOX voters' support for Trump compared

support for the US president amongst VOX's supporters. Notably, and as visualised in Figure 2, polling data signals that the electorate of VOX, vis-à-vis the electorate of other Spanish parties, is particularly inclined to sympathise with the US far-right even in comparison to their counterpart supporters of similar parties in neighbouring European states. Should our theoretical expectations regarding negative electoral contagion hold, we would expect to observe these in Spain where support for Trump among far-right voters is, comparatively, high.

Spain is, as a result, what George and Bennett (2005) pen a "most likely" case. Whilst this has potential limitations in terms of the scope conditions, it is important in terms of theory development. Given the empirical analysis we present is applied as means of presenting and testing our theoretical argument that far-right party electoral per- 
formance can engender cross-national contagion effects, relying on evidence from a "most likely" provides strong internal validity for our theoretical contribution (George \& Bennett, 2005; Yin, 2003).

\section{Data \& Identification strategy}

\subsection{Sample}

Our empirical analysis relies on data from the monthly barometer carried by the CIS in November 2020. ${ }^{7}$ Our sample contains individual level data $(\mathrm{N}=3,830)$ gathered between November 3rd and 12th. The sample was collated via three-way stratification of strata based on age, sex and region (autonomous community). Interviews were carried out using computer-assisted telephone interviewing (CATI) with $45.9 \%$ of respondents being contacted via landline telephone, and $54.1 \%$ contacted via mobile telephone. Sampling weights are provided in order for the sample to facilitate representation of population parameters.

\subsection{Empirical approach}

The identification strategy relies on the as good as random (Muñoz et al., 2020) quasiexperimental exposure to the news of the US election result on far-right support. This increasingly used approach leverages the naturally occuring assignment of survey respondents to one of two conditions: control (interviewed before loss announced) and treatment (interviewed after loss announced). This method of identifying significant discontinuities in respondetns' preferences and/or behaviours assumes that individuals naturally allocated to treatment are in fact exposed to the treatment - in this case, that Trump lost the election. Visualising the google trends data in Spain for the period

\footnotetext{
${ }^{7}$ Estudio 3300. Available at: http://www.cis.es/cis/opencm/ES/1_encuestas/estudios/ listaMuestras.jsp?estudio $=14532$
} 


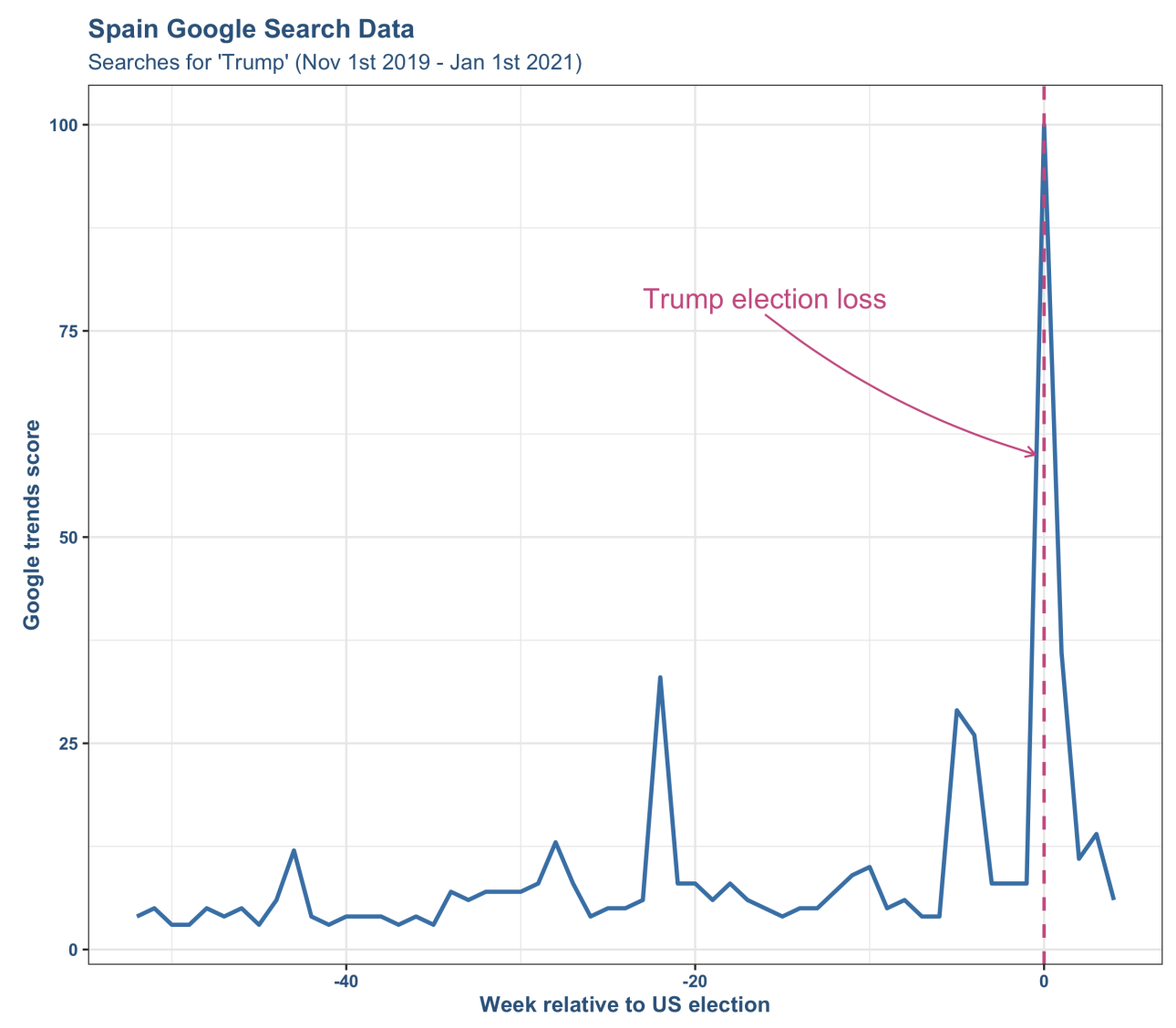

Figure 3: Treatment event saliency

of November 2019 to January 2021, Figure 3 shows a substantive spike in interest in Trump during the week of the US election, so we can be confident that widely reported news event was one that citizens in Spain were likely to be aware of. The design does not, however, have an measure of direct treatment exposure and, as a result, when we speak of treatment effects, we are making reference to treatment assignment.

To operationalise our dependent variable - far-right support - we rely on two distinct outcome measures. First, we utilise approval rating for VOX's leader, Santiago Abascal, on a ten-point (1-10) scale. Second, we rely on respondent's self-reported intentions of voting for VOX (1) or any other party (0). Both of these outcomes are expressions of far-right support and are not verified vote choices. As a result, they are potentially influenced by social expectation bias.

Treatment, based on the naturally occurring random assignment, is operationalised as: 
$T_{i}=0$ (control) if respondent $i$ interviewed before November 7 th $(\mathrm{N}=3,202)$

$T_{i}=1$ (treatment) if respondent $i$ interviewed between November 7 th $\&$ November 12 th $(\mathrm{N}=628)$

The quasi-experimental approach assumes exogenous treatment allocation independent of additional covariates. Testing for covariate balance between the treatment conditions shows that the control and treatment groups are symmetrical in terms of age, educational attainment, labour market activity, civil status, church attendance, as well as retrospective vote recall (see Figure A1). Testing for balance does show, however, that there are significantly more women in treatment than in the control group. We address this imbalance by estimating covariate-adjusted treatment effects, as well as via matching techniques and regression discontinuity approaches reported in the robustness section.

The model specification is summarised in the basic linear model (Model 1) in which $\beta_{1}$ Treatment $_{i}$ is the covariate-adjusted average treatment effect (ATE), $\gamma X_{i}$ is a vector of individual covariates and $\epsilon_{i}$ is the error term:

$$
Y_{i}=\alpha+\beta_{1} \text { Treatment }_{i}+\gamma X_{i}+\epsilon_{i}
$$

In the results section we present the estimand of interest both with and without covariateadjustment. Covariates considered in the main models include: sex, age, education, employment status, civil status and religious attendance, all of which we assume to be causally anterior to treatment allocation. Models including regional fixed effects are also reported in the Appendix (Table A6) and replicate the findings reported below. Summary statistics, covariate operationalisation and question wordings are reported in the Online Appendix material. 


\section{Results}

\subsection{Main analysis}

The primary findings are illustrated in Figure 4 (full regression output in Table A4). In the case of both support for VOX's leader as well as the probability of voting for VOX, we observe that those interviewed immediately after the announcement of the US election results were significantly less likely to support Spain's far-right party.

\section{Estimated treatment effects}

Effect of Trump election loss on support for VOX

Support for Abascal (1-10)
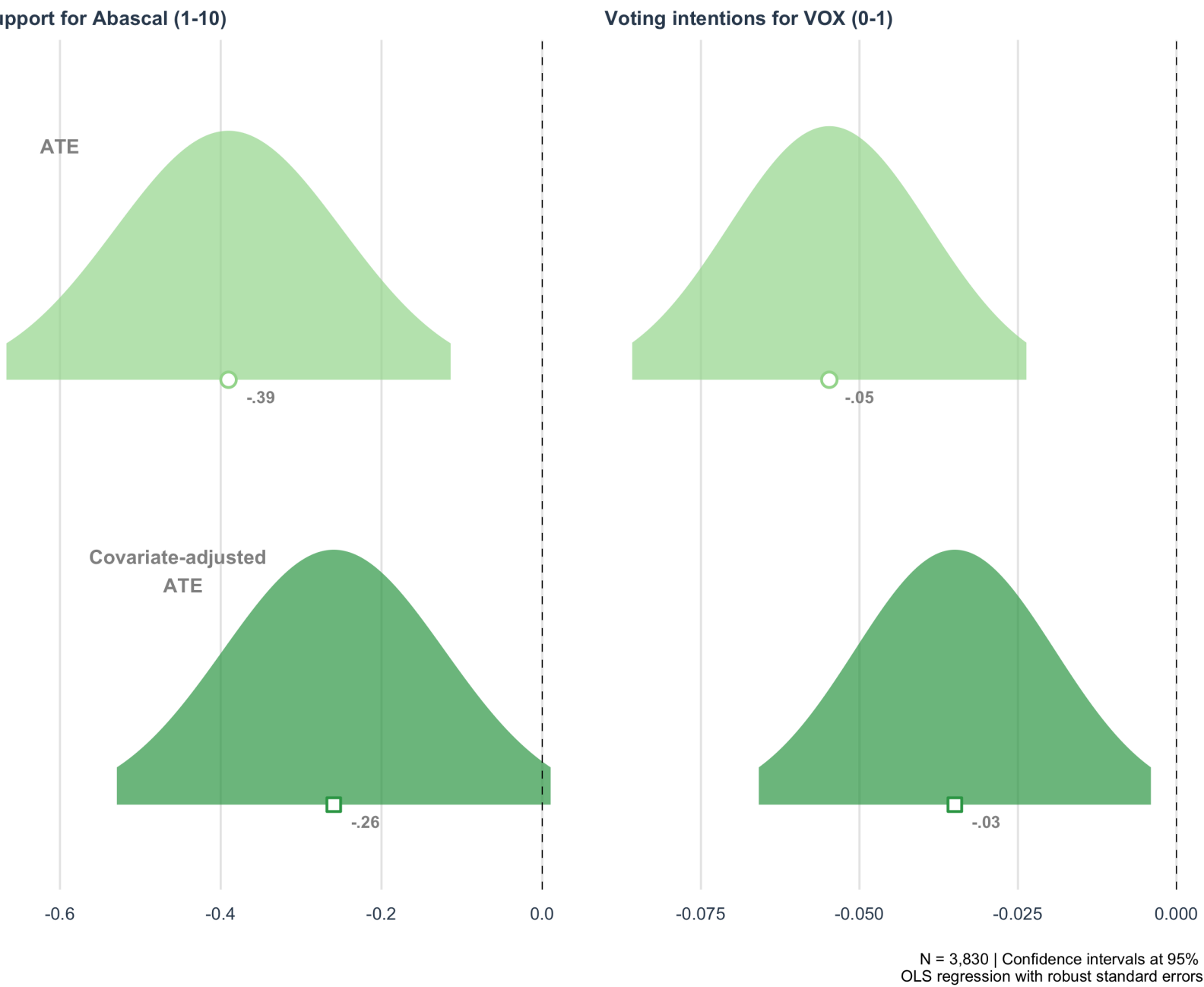

Figure 4: Estimated treatment effects on main outcomes

The ATE on approval for Abascal (left-hand panel) is substantive at -.39 : equivalent to a fall of $17 \%$ relative the control group mean. Adjusting the ATE to accommodate 
covariates provides a point-estimate of $-.26(p<0.06)$. Similar negative contagion effects are found in the case of the probability of voting for VOX (right-hand panel). On average, those interviewed after Trump's loss were 5 percentage-points less likely to vote for VOX compared to those interviewed before the results were known (a fall equal to $71 \%$ relative control). Adjusting the estimated ATE for covariates, does little to alter the effect of the election, with the covariate-adjusted ATE equal to 3 percentagepoints.

In terms of how these findings relate to our alternative hypotheses: the results present empirical evidence in support of the legitimacy thesis and contradict the expectations of the backlash thesis. In other words, we do not find any evidence that the loss of an important far-right leader abroad can mobilise potential far-right sympathisers to retaliatory fashion. Instead we argue that these findings are likely the result of individuals viewing the loss of Trump as indicative of the far-right's limited viability.

\subsection{Conditional effects}

Given the theorised mechanism that we present is that those with the potential to be inclined to support VOX will be deterred from doing so when they are exposed to signals that the far-right is in decline, we expect that the support-reducing effects are likely to only be observed amongst those who spatially identify on the right of the left-right ideological divide. To test this expectation, we replicate Model 1 to include a multiplicative interaction term between treatment assignment and right-wing ideological identification (Model 2).

$$
Y_{i}=\alpha+\beta_{1} \text { Treatment }_{i} * \delta_{1} \text { RightWing Voter }_{i}+\gamma X_{i}+\epsilon_{i}
$$

Figure 5 reports the predicted margins of treatment for left-wing and right-wing vot- 
ers and demonstrates the asymmetric effects of treatment (see also Table A5). As expected, whilst there is a sizeable and significant $(p<0.001)$ fall in express approval for Abascal among those who identify on the right (-.76), there is no significant change amongst left-wing voters (.067). When we consider the probability of voting for VOX, a similar relationship is observed: right-wing voters in the treatment condition are 11 percentage-points less likely to report an intention of voting for VOX vis-à-vis the control group (equal to a $65 \%$ change relative the control mean). Whilst left-wing observe a 2 percentage-point decrease, the point-estimate of the ATE is indistinguishable from zero.
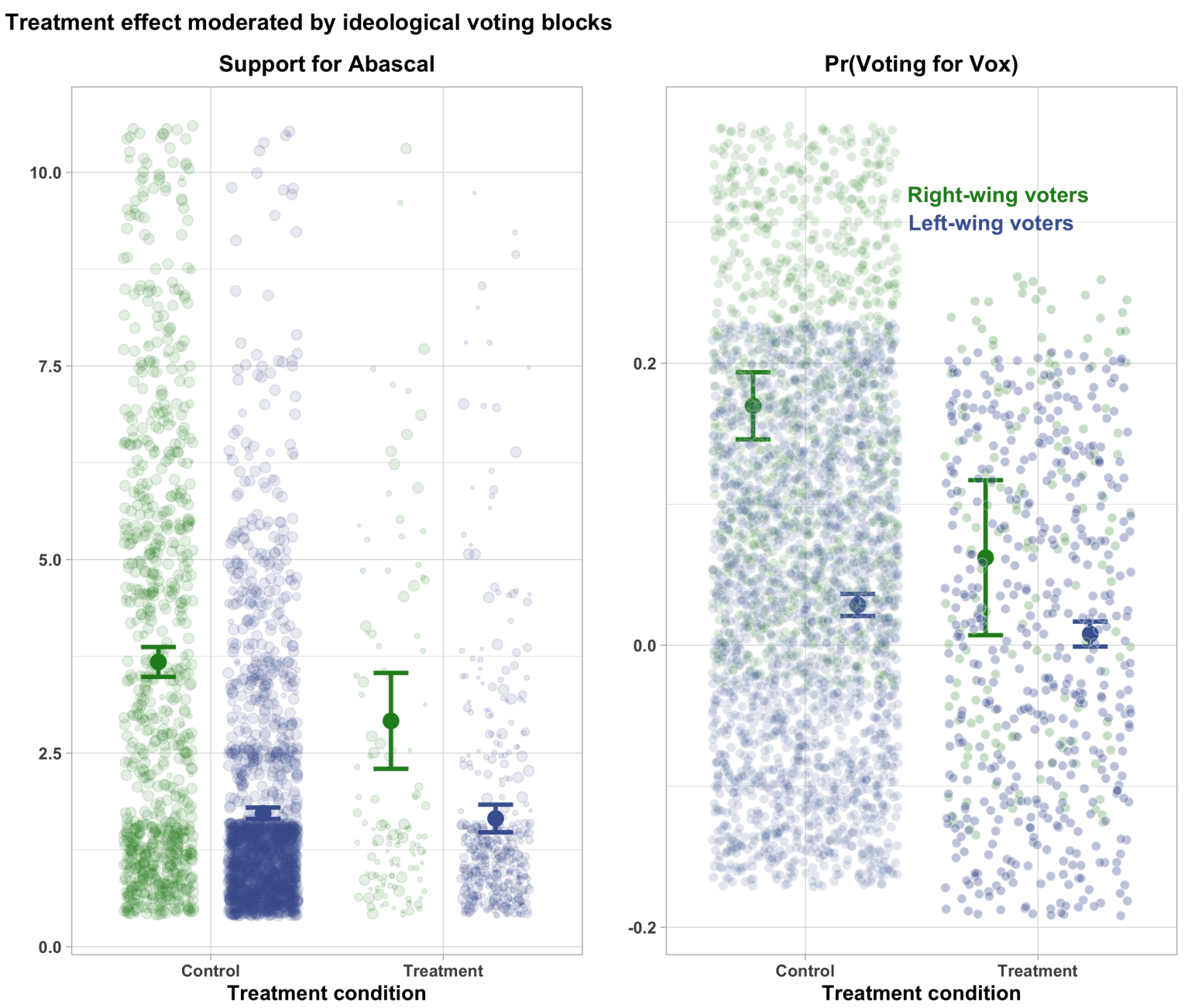

Figure 5: Asymmetric treatment effects

In order to demonstrate our results are unique to support for VOX rather than support for right-wing parties in general, we re-estimate our analyses on support for the 

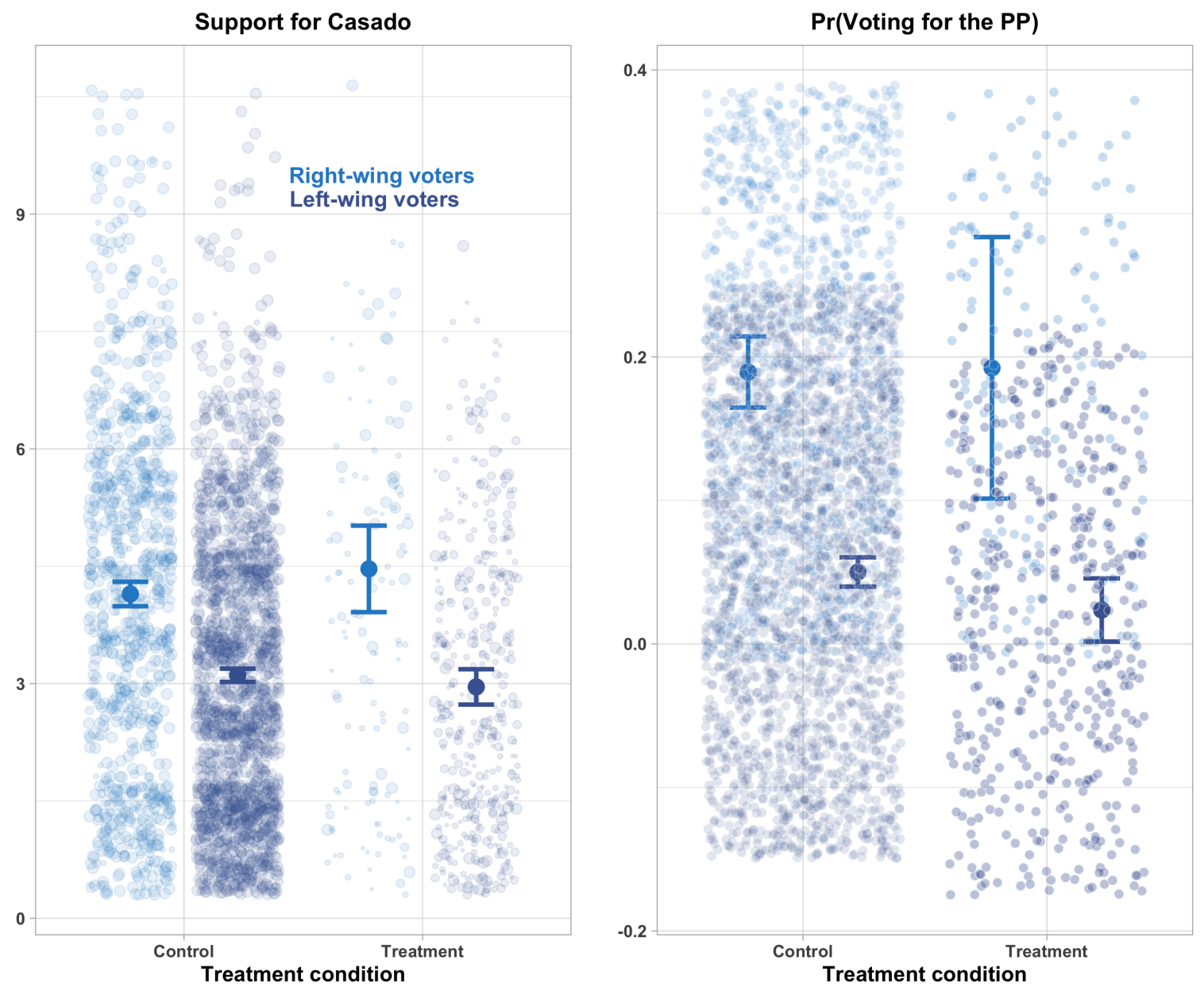

Figure 6: Asymmetric treatment effects on placebo (PP)

Spain's mainstream right-wing party. Figure 6 illustrates the results of the same specification (Model 2) on support for the mainstream right-wing party, the People's Party (PP), and shows that the electoral loss of the US far-right played no role of significance or substance on individuals' expression of endorsement for the mainstream right among left-wing or right-wing voters. The effect of Trump's electoral defeat, in line with our theoretical argument, only impacted respondents' (self-reported) support for the radical right-wing party. 


\section{Robustness checks}

\subsection{RDD approach}

In order to support our empirical claims that the announcement of the electoral defeat of the US far-right represented a significant discontinuity in support for VOX, we replicate our findings using a regression discontinuity design (RDD). Figure 7 demonstrates that in the case of both measures of support for the Spanish far-right, the announcement of the Trump defeat engendered a significant discontinuity. In the case of support for Abascal the point-estimate of the discontinuity (local linear) is equal to .49 $(p=0.04)$. In the case of voting intentions, the discontinuity is equal to 3 percentagepoints but fails to comply with conventional statistical significance $(p<0.1)$. Higher order polynomials provide a better fit for data and lead to the reporting of symmetrical point-estimates that are statistically distinguishable from zero in the case of both outcome measures. Their use in RDD estimations, however, is not without critique and Gelman and Imbens (2019) argue that local linear estimations provide for more conservative estimations. Full RDD estimations, including a comparison of higher-order polynomials, are reported in Table A9.

\subsection{Sensitivity tests \& identification threats}

The excludability assumption requires that any significant differences between the allocation to treatment and control conditions is not the result of other simultaneous effects. To check for this, and in line with similar research designs (Bol et al., 2021), we estimate permutation tests to ensure that our results are not spurious. Reproducing the analysis by randomly assigning the treatment date associated with individual respondents in 1,000 iterations (Figure 8), we show that the observed effects are significantly distinct from the null effects of the permutations. Assessing the sensitivity of our analysis across multiple different bandwidths on either side of the threshold, as 

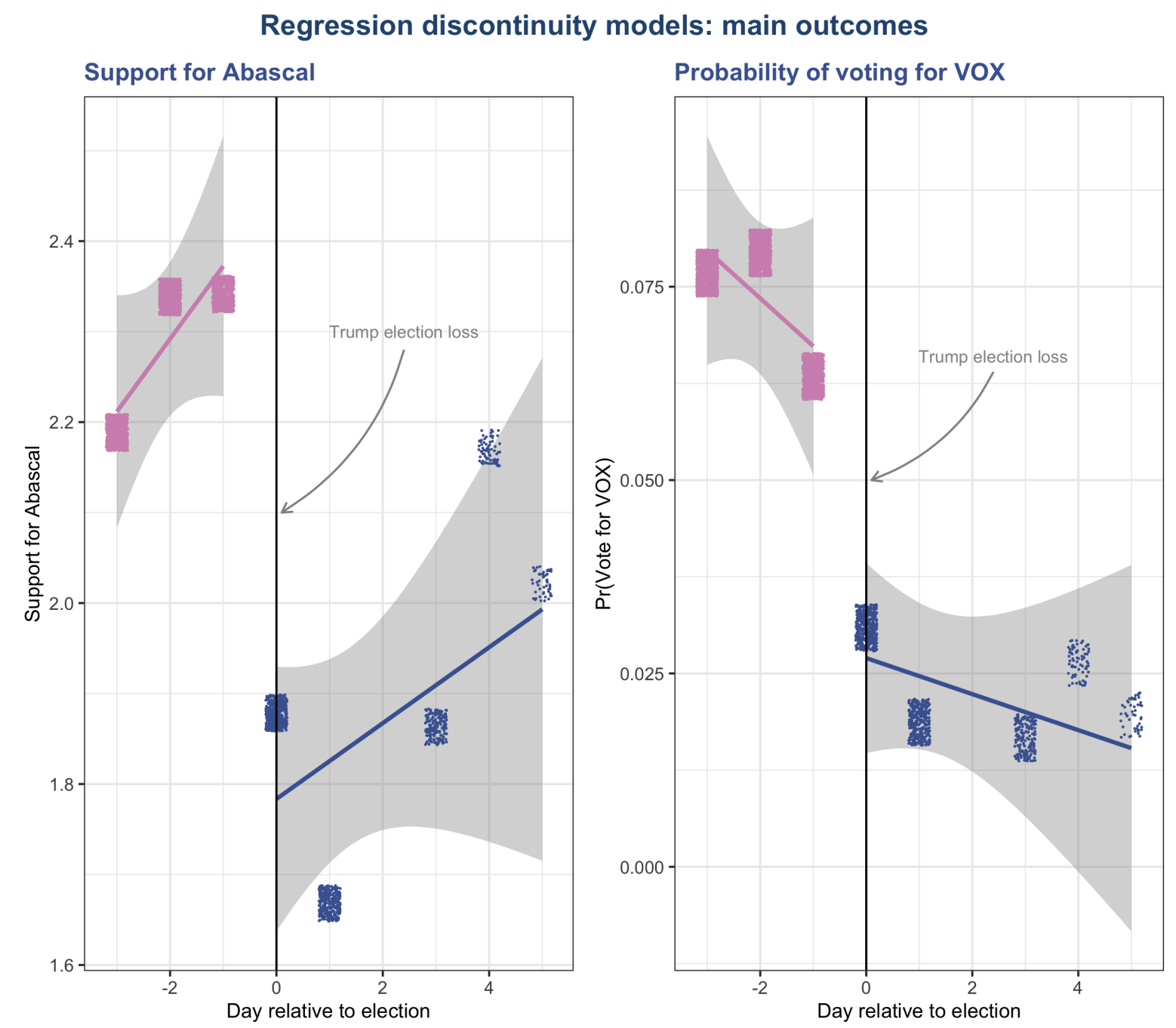

Figure 7: Alternative estimation: RDD

recommended by Muñoz et al. (2020), does not condition our findings. As visualised in Figure 9 the point-estimate of our estimated treatment effect remains largely constant across different bandwidth sizes if, however, statistical significance is lost in the case of voting intentions for VOX when the bandwidth is at its most restricted.

In addition to the RDD model and the permutation test that rule out any spurious effects that might be brought about by pre-existing time trends, we also demonstrate that there is a null effect of different placebo issues that, should our theoretical argument hold, we would expect to be independent of treatment assignment. Figure 10 illustrates the (lack of) discontinuity in evaluations towards the economy (left-hand panel) and concerns about Covid-19 (right-hand panel). In the case of both placebo is- 

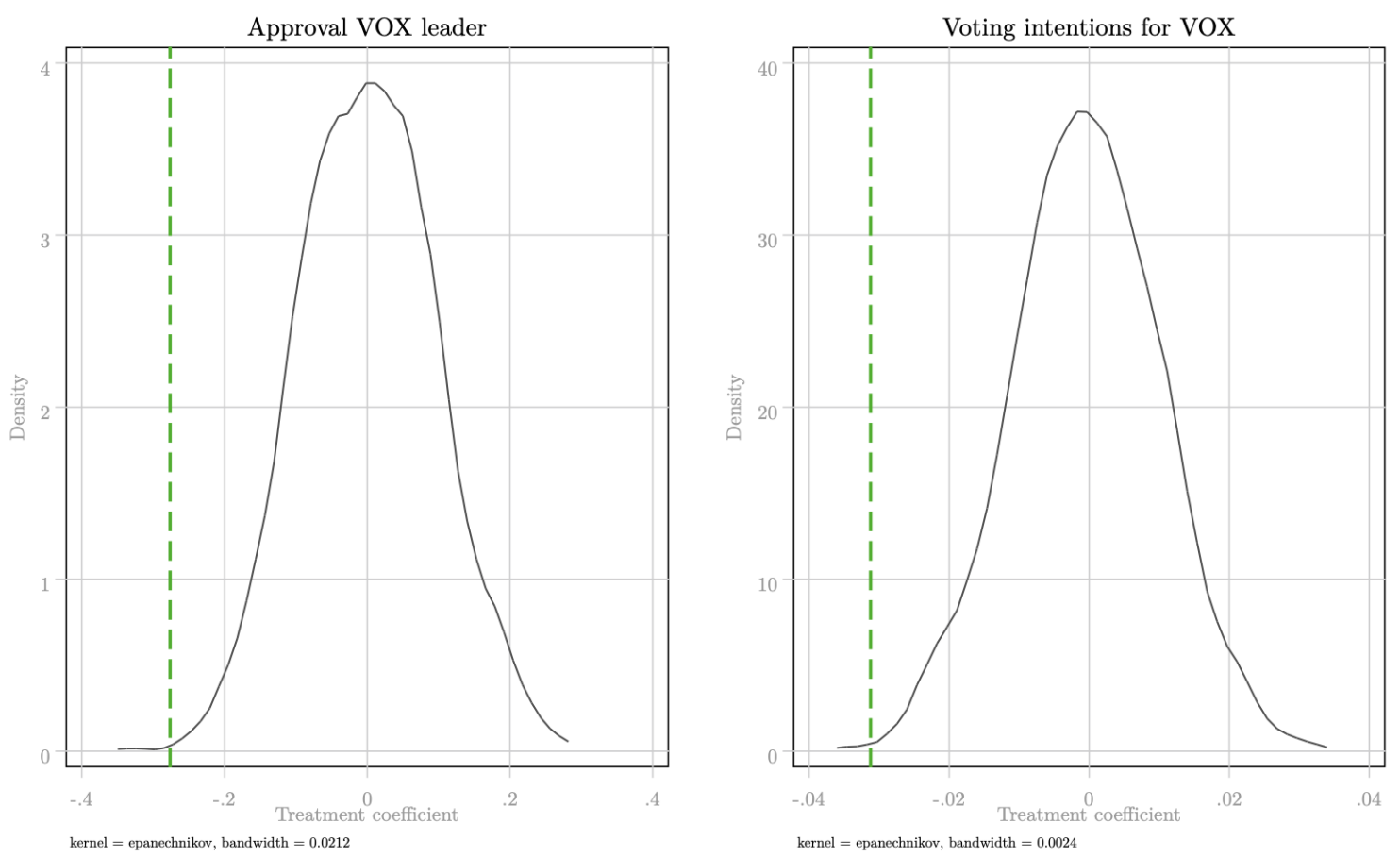

Figure 8: Randomisation inference test

sues, we do not observe a significant effect associated with treatment allocation at the threshold. We can, therefore, be confident that any significant effects in support for VOX caused by treatment are not the result of a confounding shift in general attitudes or evaluations. ${ }^{8}$

The ignorability assumption requires that treatment assignment be independent of potential outcomes and the pre-treatment covariates that predict outcome variables. To ensure compliance with ignorability we test for balance in treatment assignment and balance in rates of attrition. Quasi-random allocation to the two treatment conditions is not dependent on identifiable covariates, with the exception of gender. And, as displayed in Table A3, there is no significant variation in attrition rates between treatment groups. As a further robustness check of the ignorabiity assumption, and in addition to covariate-adjusted models presented above, we also estimate a sensitivity test relying on nearest-neighbour matching - as recommended by Muñoz et al. (2020) - in

\footnotetext{
${ }^{8}$ Whilst other issue-specific placebos like concerns over immigration would be valuable tests, the monthly barometer does not include any other issue-specific placebos that we can test.
} 


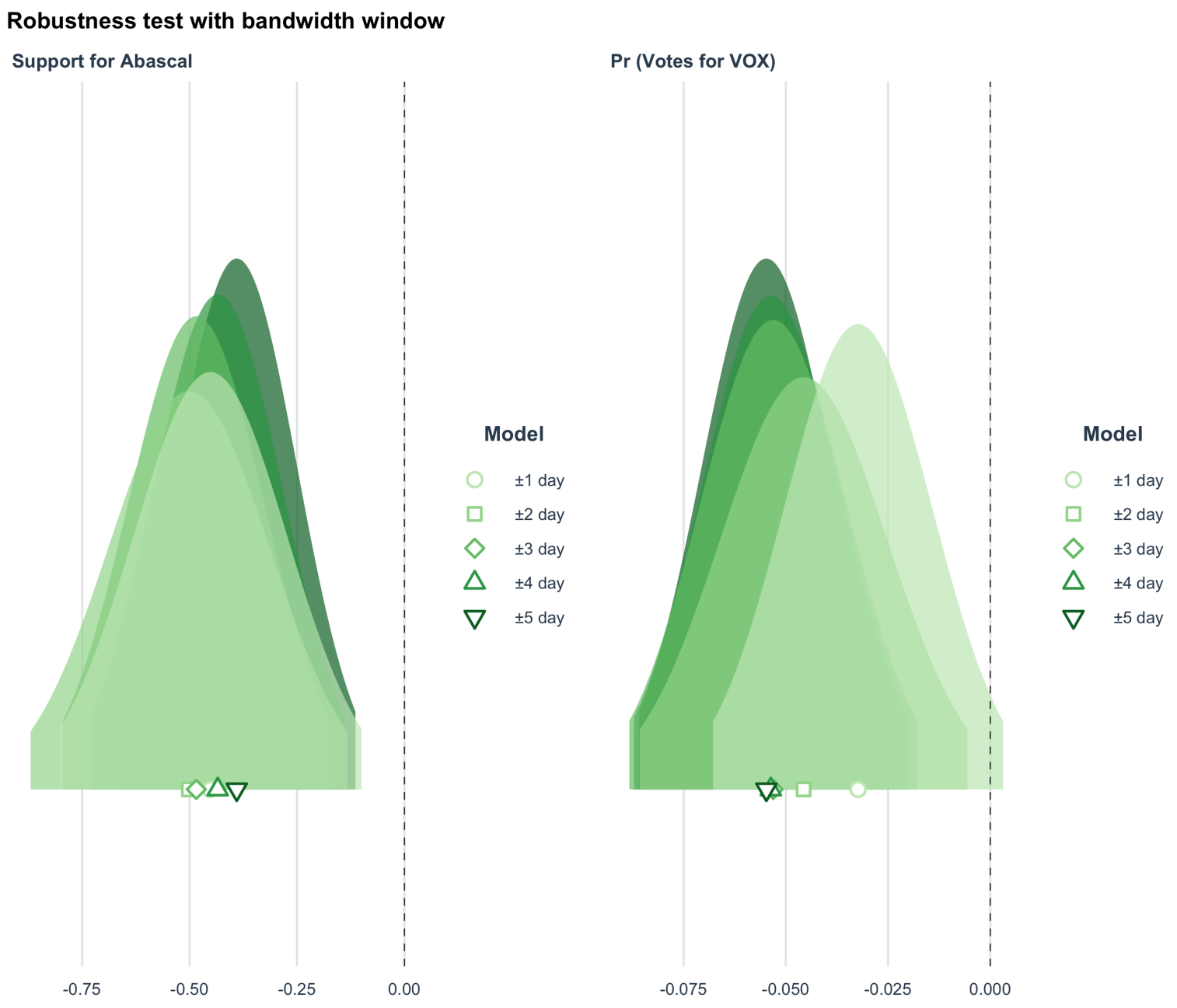

Figure 9: Bandwidth sensitivity test

order to ensure that our results are not the product of potential imbalances. The output of these matching estimations, reported in Figure A2, provide additional empirical support for our conclusions.

\section{Conclusion}

In this article we make an important theoretical and empirical contribution. Theoretically, we argue that the signalling effects of far-right party success and failures are not limited to the confines of national boundaries. In line with work that signals the crossnational diffusion of far-right development (Rydgren, 2005; Van Hauwaert, 2019), we maintain that signals of far-right party performance also diffuse beyond the national 
Regression discontinuity models: Placebos
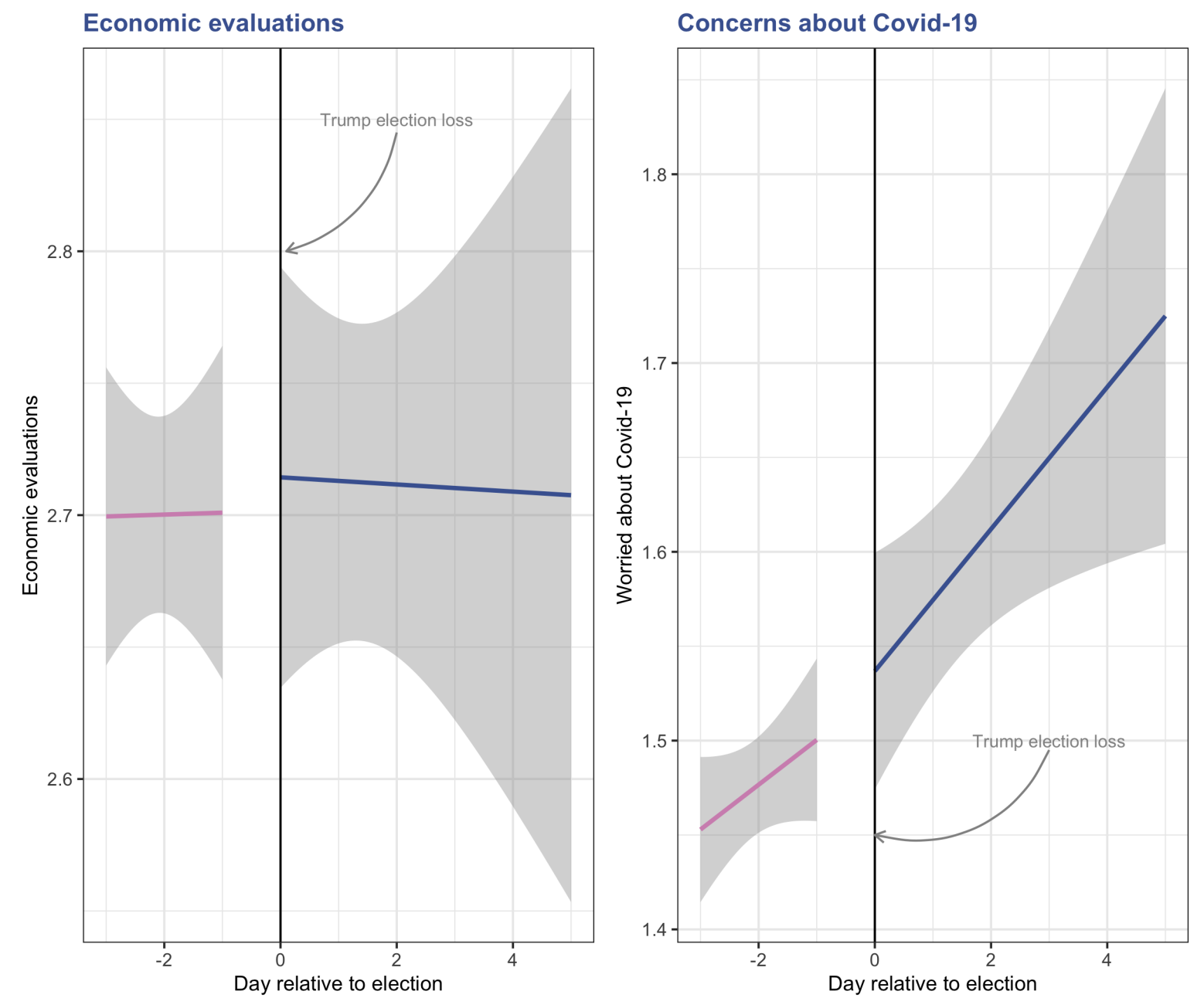

Figure 10: Placebo issues

context.

Empirically and leveraging the quasi-experimental setting afforded by the 2020 US election result's coincidental timing with Spain's monthly electoral barometer, we present robust causal evidence demonstrating that the electoral defeat of Donald Trump - as a transnational figure of far-right (Mudde, 2016) - engendered a collapse in support for Spain's new radical right-wing party VOX. Our results are constant across multiple empirical tests including regression discontinuity models, nearest-neighbour matching, regional fixed-effect models and alternative placebos. Additionally, and in line with our theoretical argument, the effect of treatment is conditioned by ideological identification. We observe a precise null effect amongst those who identify with the 
left, signalling that Trump's electoral loss had no influence on their attitudes towards the far-right, whilst there is a sizeable and significant effect amongst those who identify on the right.

Our findings speak to various pieces of literature. First, we provide empirical support to the growing body of empirical work that demonstrates the substantive causal impact salient political events of individual electoral preferences and attitudes. Not only do we find that salient events matter but, in line with the work of Giani and Meón (2019), Delis et al. (2020) and Turnbull-Dugarte (2021), we also demonstrate that cross-national spillover effects can causally influence electoral preferences and public opinion. Second, we add to the literature (Rydgren, 2005; Van Hauwaert, 2019) that address the transnational nature of far-right parties. We demonstrate the the losses of one branch of the movement does not come without potential consequences for comparable branches operating in different states.

Finally, whilst our results illustrate that Trump's electoral defeat has struck a blow against the far-right in Spain (at least in the immediate short term), we are cautious in our interpretation of these results. Our findings do not lead us to support any conclusions regarding Trump's demise signalling a reversal of the trajectory of farright success in the long-term. As detailed by Bale and Rovira Kaltwasser (2021) and also Mudde (2019), the ascendancy of far-right parties does not appear to be stagnating including in Spain.

One limitation of our design is the inability to test which of the two underlying mechanism we posit to be behind the legitimacy hypothesis we present. We argue that the drop in self-reported support for VOX and the party's leader is likely the result of Trumps' defeat serving as a cue that informs individuals who may be sympathetic towards voting for VOX regarding the (lack of) viability of this kind of party. An alternative explanation, however, is that the results are driven by individuals opting to mask their authentic preferences. A widely reported defeat for the far-right may reinvigorate the perceived undesirability of these parties and, as a result, increase the 
constraining effect of social expectation bias in communicating survey responses.

Future work may seek to assess under what conditions cross-national spillover effects take place among far-right party networks or across different party families. Bischof and Wagner (2019) demonstrate that the far-right victories have legitimising effects domestically, whilst we show that losses for these parties can have undermining effects transnationally. More research is required to assess whether these legitimising and undermining effects can work both domestically and transnationally across both victories and losses, or if, for example, the direction of the electoral result matters.

\section{References}

Abou-Chadi, T. (2016). Niche Party Success and Mainstream Party Policy Shifts - How Green and Radical Right Parties Differ in Their Impact. British Journal of Political Science, 46(2), 417-436.

Abou-Chadi, T., \& Stoetzer, L. F. (2020). How Parties React to Voter Transitions. American Political Science Review, 114(3), 241-262.

Abou-Chadi, T., \& Wagner, M. (2020). Electoral fortunes of social democratic parties: do second dimension positions matter? Journal of European Public Policy, 27(2), $246-272$.

Abou-Chadi, T., \& Werner, K. (2020). The Causal Effect of Radical Right Success on Mainstream Parties' Policy Positions: A Regression Discontinuity Approach. British Journal of Political Science, 50(3), 829-847.

Ares, M., \& Hernández, E. (2017). The corrosive effect of corruption on trust in politicians: Evidence from a natural experiment. Research and Politics, 4(2), 1-8. https: / / doi.org/10.1177\2F2053168017714185

Aytac, S., \& Carkoglu, A. (2019). Terror attacks, issue salience, and party competence: Diagnosing shifting vote preferences in a panel study. Party Politics, Online First. https: / / doi.org/10.1177\\%2F1354068819890060 
Bale, T., \& Rovira Kaltwasser, C. (2021). Riding the Populist Wave. Europe's Mainstream Right in Crisis. Cambridge University Press.

Bicchieri, C. (2016). Norms in the Wild: How to Diagnose, Measure, and Change Social Norms. Oxford University Press.

Bischof, D., \& Wagner, M. (2019). Do Voters Polarize When Radical Parties Enter Parliament? American Journal of Political Science, 63(4), 888-904.

Bol, D., Giani, M., Blais, A., \& Loewen, P. J. (2021). The effect of COVID-19 lockdowns on political support: Some good news for democracy? European Journal of Political Research, 60(2), 497-505.

Bridgman, A., Ciobanu, C., Erlich, A., Bohonos, D., \& Ross, C. (2020). Unveiling: the Electoral Consequences of an Exogenous Mid-Campaign Court Ruling. Journal of Politics, Online First. https: / / doi.org/10.1086/711177

Cervilla, P. (2020). La salida de Trump deja a VOX sin su referente americano. $A B C$ España, November 30th.

Chang, C.-P., \& Berdiev, A. N. (2015). Do natural disasters increase the likelihood that a government is replaced? Applied Economics, 47(17), 1788-1808.

Delis, A., Matakos, K., \& Xefteris, D. (2020). Electoral spillovers in an intertwined world: Brexit Effects on the 2016 Spanish Vote. British Journal of Political Science, 50(3), 1169-1174.

Devine, D. (2021). Discrete Events and Hate Crimes: The Causal Role of the Brexit Referendum. Social Science Quarterly, 102(1), 374-386.

Dinas, E., Matakos, K., Xefteris, D., \& Hangartner, D. (2019). Waking Up the Golden Dawn: Does Exposure to the Refugee Crisis Increase Support for Extreme-Right Parties? Political Analysis, 27(2), 224-254.

Edwards, G. S., \& Rushin, S. (2018). The Effect of President Trump's Election on Hate Crimes. SSRN, Online First. https://doi.org/10.2139/ssrn.3102652

Ferrín, M., Mancosu, M., \& Capppiali, T. M. (2020). Terrorist attacks and Europeans' attitudes towards immigrants: An experimental approach. European Journal of Political Research, 59(3), 491-516. 
Gelman, A., \& Imbens, G. (2019). Why High-Order Polynomials Should Not Be Used in Regression Discontinuity Designs. Journal of Business E Economics Statistics, $37(3), 447-456$.

George, A. L., \& Bennett, A. (2005). Case Studies and Theory Development in the Social Sciences. MIT Press.

Giani, M. (2020). Fear without Prejudice in the Shadow of Jihadist Threat. Comparative Political Studies, Online First. https:/ / doi.org/10.1177\\%2F0010414020957680

Giani, M., \& Meón, P. G. (2019). Global Racist Contagion following Donald Trump's Election. British Journal of Political Science, Online First. https: / / doi .org / 10. $1017 /$ S0007123419000449

Halikiopoulou, D., \& Vlandas, T. (2020). When economic and cultural interests align: the anti-immigration voter coalitions driving far right party success in Europe. European Political Science Review, 12(4), 427-448.

Krause, W., Cohen, D., \& Abou-Chadi, T. (2019). Does Accommodation Work? Mainstream Party Strategies and the Success of Radical Right Parties. Online Working Paper.

Kuyper, J., \& Moffit, B. (2019). Transnational Populism, Democracy, and Representation: Pitfalls and Potentialities. Global Justice: Theory Practice Rhetoric, 12(2), 2749.

Mendes, M. S., \& Dennison, J. (2021). Explaining the emergence of the radical right in Spain and Portugal: salience, stigma and supply. West European Politics, 44(4), $752-775$.

Minkus, L., Deutschmann, E., \& Delhey, J. (2019). A trump effect on the EU's popularity? The U.S. Presidential election as a natural experiment. Perspectives on Politics, 17(2), 399-416.

Moffit, B. (2017). Transnational Populism? Representative Claims, Media and the Difficulty of Constructing a Transnational "People". Javnost - The Public. Journal of the European Institute for Communication and Culture, 24(4), 409-425. 
Montalvo, J. G. (2011). Voting after the bombings: A natural experiment on the effect of terrorist attacks on democratic elections. Review of Economics and Statistics, 93(4), 1146-1154.

Mudde, C. (2016). Europe's far right has been boosted by Trump's win - for now. The Guardian, November 9th.

Mudde, C. (2017). The Far Right in America. Routledge.

Mudde, C. (2019). The Far-Right Today. Polity Press.

Muñoz, J., Falcó-Gimeno, A., \& Hernández, E. (2020). Unexpected Event during Survey Design: Promise and Pitfalls for Causal Inference. Political Analysis, 28(2), 186-206.

Neundorf, A., \& Pardos-Prado, S. (2020). The Impact of Covid-19 on Trump's Electoral Demise. SocArxiv, Online. https://doi.org/10.31235/osf.io/cg3fm

Newman, B., Merolla, J. L., Shah, S., Casarez Lemi, D., Collingwood, L., \& Ramakrishnan, S. K. (2020). The Trump Effect: An Experimental Investigation of the Emboldening Effect of Racially Inflammatory Elite Communication. British Journal of Political Science, Online First. https: / / doi.org/10.1017/S0007123419000590

Norris, P. (2020). Measuring populism worldwide. Party Politics, 26(6), 697-717.

Norris, P., \& Inglehart, R. (2019). Cultural Backlash. Trump, Brexit, and Authoritarian Populism. Cambridge University Press.

Rama, J., \& Casal Bértoa, F. (2020). Are Anti-Political-Establishment Parties a Peril for European Democracy? A Longitudinal Study from 1950 till 2017. Representation, 56(3), 387-410.

Rama, J., Zanotti, L., Turnbull-Dugarte, S. J., \& Santana, A. (2021). VOX: The Rise of Spanish Populist Radical Right. Routledge.

Rydgren, J. (2005). Is extreme right-wing populism contagious? Explaining the emergence of a new party family. European Journal of Political Research, 44, 413-437.

Rydgren, J. (2007). The Sociology of the Radical Right. Annual Review of Sociology, 33, 241-262. 
Santana, A., Ziagórski, P., \& Rama, J. (2020). At odds with Europe: explaining populist radical right voting in Central and Eastern Europe. East European Politics, 36(2), 288-309.

Tankard, M. E., \& Palcuk, E. L. (2016). Norm Perception as a Vehicle for Social Change. Social Issues and Policy Review, 10(1).

Turnbull-Dugarte, S. J. (2019). Explaining the end of Spanish exceptionalism and electoral support for Vox. Research and Politics, 6(2), 1-8. https: / / doi.org/10.1177 $\% 2 F 2053168019851680$

Turnbull-Dugarte, S. J. (2020). A new hope for europhiles? The 2017 German federal elections and the revenge of the pro-European mainstream. Journal of European Integration, Online First. https:/ / doi.org/10.1080/07036337.2020.1826943

Turnbull-Dugarte, S. J. (2021). Homonegative attitides after Obergefell v. Hodges. Quasiexperimental evidence of anticipatory backlash abroad. OSF Pre-print. https: / / doi.org/10.31219/osf.io/7jmn4

Valentim, V. (2021). Parliamentary Representation and the Normalization of Radical Right Support. Comparative Political Studies, Online First. https: / / doi.org /10. $1177 \backslash \% 2 F 0010414021997159$

Van Hauwaert, S. M. (2019). On far right parties, master frames and trans-national diffusion: understanding far right party development in Western Europe. Comparative European Politics, 17, 132-154.

Vasilopoulou, S. (2018). Far Right Parties and Euroscepticism: Patterns of Opposition. Rowman.

Wondreys, J., \& Mudde, C. (2020). Victims of the Pandemic? European Far-Right Parties and COVID-19. Nationalities Papers, Online First. https:/ / doi.org/10.1017/ nps.2020.93

Yin, R. K. (2003). Case Study Research: Design and Methods. SAGE Publications. 


\section{Appendix}

\section{A Descriptive statistics and variable description}

Table A1: Summary statistics

\begin{tabular}{lccccc}
\hline Variable & $\mathbf{N}$ & Mean & Standard deviation & Min & Max \\
\hline Support Abascal & 3483 & 2.164 & 2.066 & 1.000 & 10.000 \\
Support Casado & 3548 & 3.315 & 2.009 & 1.000 & 10.000 \\
Vote for VOX & 3830 & 0.060 & 0.238 & 0.000 & 1.000 \\
Vote for PP & 3830 & 0.081 & 0.273 & 0.000 & 1.000 \\
Worried about Covid & 3826 & 1.505 & 0.710 & 1.000 & 5.000 \\
Worried about economy & 3808 & 2.704 & 0.994 & 1.000 & 5.000 \\
Treatment & 3830 & 0.164 & 0.370 & 0.000 & 1.000 \\
Sex & 3830 & 0.515 & 0.500 & 0.000 & 1.000 \\
Age & 3830 & 51.108 & 16.958 & 18.000 & 94.000 \\
Education & 3830 & 4.616 & 1.483 & 1.000 & 7.000 \\
Civil status & 3830 & 1.776 & 1.148 & 1.000 & 9.000 \\
Church attendance & 3830 & 1.170 & 1.427 & 0.000 & 9.000 \\
Employment status & 3830 & 2.088 & 1.644 & 1.000 & 9.000 \\
\hline
\end{tabular}


Table A2: Question wording \& variable operationalisation

\begin{tabular}{|c|c|c|}
\hline Variable & Question & Operationalisation \\
\hline Support Abascal & $\begin{array}{l}\text { What evaluation would you give each of the following politicians on a scale from } 1 \text { to } 10 \text {, } \\
\text { where } 1 \text { means "very bad" and } 10 \text { means "very good" - Santiago Abascal }\end{array}$ & $\begin{array}{l}1-\text { Very bad } \\
2,3,4,5,6,7,8,9 \\
10 \text { - Very good }\end{array}$ \\
\hline Support Casado & $\begin{array}{l}\text { What evaluation would you give each of the following politicians on a scale from } 1 \text { to } 10 \text {, } \\
\text { where } 1 \text { means "very bad" and } 10 \text { means "very good" - Pablo Casao }\end{array}$ & $\begin{array}{l}1-\text { Very bad } \\
2,3,4,5,6,7,8,9 \\
10 \text { - Very good } \\
\end{array}$ \\
\hline Vote for VOX & $\begin{array}{l}\text { Supposing that tomorrow there was a general election, that is an election for } \\
\text { the national parliament, which party would you likely vote for? }\end{array}$ & $\begin{array}{l}\text { - Vote VOX } \\
0 \text { - Any other alternative }\end{array}$ \\
\hline Vote for PP & $\begin{array}{l}\text { Supposing that tomorrow there was a general election, that is an election for } \\
\text { the national parliament, which party would you likely vote for? }\end{array}$ & \begin{tabular}{|l|l|}
1 - Vote PP \\
0 - Any other
\end{tabular} \\
\hline Worried about Covid & $\begin{array}{l}\text { Thinking about the effects of the pandemic, would you say that you are very worried } \\
\text {, quite worried, little worried or not at all worried? }\end{array}$ & $\begin{array}{l}\text { - Very worried } \\
2 \text { - Quite worried } \\
3 \text { - Regular (spontaneous) } \\
4 \text { - Little worried } \\
5 \text { - Not at all worried }\end{array}$ \\
\hline Worried about economy & $\begin{array}{l}\text { How would you evaluate your current personal economic situation: } \\
\text { very good, good, bad, or very bad? }\end{array}$ & $\begin{array}{l}\text { - Very Good } \\
2 \text { - Good } \\
3 \text { - Regular (spontaneous) } \\
4 \text { - Bad } \\
5 \text { - Very bad }\end{array}$ \\
\hline Treatment & $\mathrm{N} / \mathrm{A}$ & $\begin{array}{l}0 \text { - Interviewed before November } 7 \text { th } \\
1 \text { - Interviewed on or after November } 7 \text { th }\end{array}$ \\
\hline Education & $\begin{array}{l}\text { What is the highest level of education you have participated in } \\
\text { (regardless of whether or not you finished)? }\end{array}$ & $\begin{array}{l}1 \text { - None } \\
2 \text { - Primary } \\
3 \text { - Secondary (lower) } \\
4 \text { - Secondary (higher) } \\
5 \text { - Further education } \\
6 \text { - Higher education } \\
7 \text { - Other } \\
\end{array}$ \\
\hline Civil status & What is your civil status? & \begin{tabular}{|l} 
1- Married \\
2- Single \\
3 - Widowed \\
4 - Separated \\
5 - Divorced \\
6 - No answer
\end{tabular} \\
\hline Church attendance & $\begin{array}{l}\text { How often do you attend mass or other religious events, without counting weddings, } \\
\text { funerals and other social religious ceremonies? }\end{array}$ & $\begin{array}{l}\text { - Almost never } \\
2 \text { - Multiple times a year } \\
3 \text { - One a month } \\
4 \text { - Almost always } \\
5 \text { - Multiple times a week } \\
6 \text { - Non-practitioner } \\
7 \text { - No answer } \\
\end{array}$ \\
\hline Employment status & In what employment situation do you currently find yourself? & $\begin{array}{l}\text { - Working } \\
\text { 2 - Retired (worked before) } \\
3 \text { - Retired (didn't work before) } \\
\text { - - Unemployed (worked before) } \\
5 \text {-Unemployed (didn't work before } \\
6 \text { - Studying } \\
7 \text { - Unpaid domestic work } \\
\text { 8- Other situation } \\
9 \text { - No answer } \\
\end{array}$ \\
\hline
\end{tabular}




\section{B Balance test}

\section{Balance test}

Voted:Cs

Voted: PP

Voted: Other

Voted: PSOE

Voted: UP

Voted:VOX

Sex(Male)

Age

Studies: other

Studies:Primary

Studies: Secondary1

Studies: Secondary2

Studies: None

Work: Unemployed + worked before

Work: Studying

Work: Unknown

Work: Other

Work: Working

Work: Domestic

CivilStat: Divorced

CivilStat: Unknown

CivilStat: Separated

CivilStat: Single

CivilStat: Widow(er)

Churchgoer: Almost never

Churchgoer: Almost always

Churchgoer: Multiple times a week

Churchgoer: Don't know

Churchgoer: Non-practioner

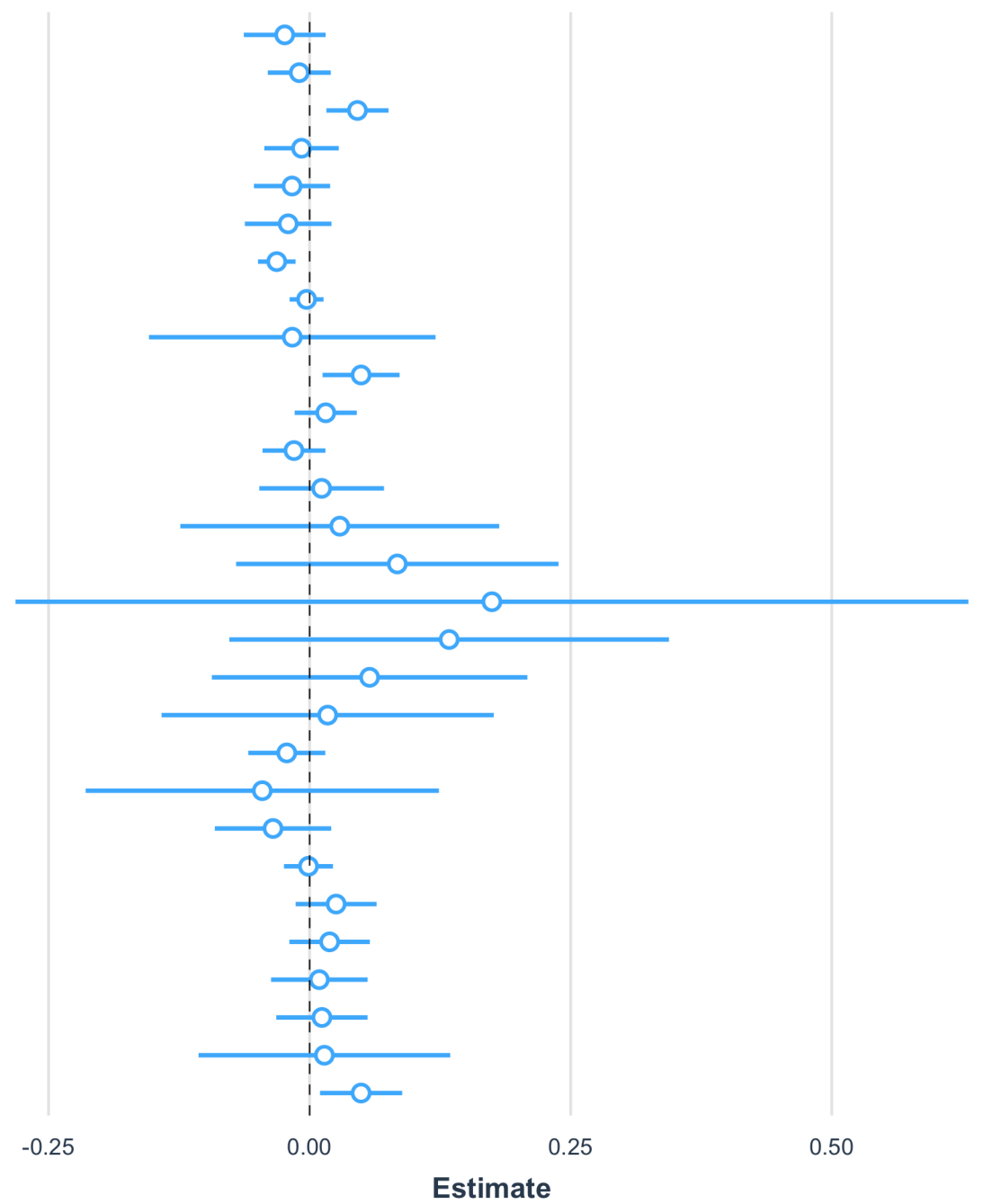

OLS model of pre-treatment covariates predicting treatment assignment

Figure A1: Balance of treatment assignment 
Table A3: Missing outcome data by treatment condition

(1)

Attrition Attrition Attrition

\begin{tabular}{lccc}
\hline Treatment & 0.03 & 0.00 & -0.00 \\
& $(0.02)$ & $(0.02)$ & $(0.02)$ \\
Controls & No & Yes & Yes \\
Regional FE & No & No & Yes \\
Constant & $0.09^{* * *}$ & $0.25^{* * *}$ & $0.25^{* * *}$ \\
& $(0.01)$ & $(0.06)$ & $(0.06)$ \\
& & & \\
\hline Observations & 3,830 & 3,830 & 3,830 \\
R-squared & 0.00 & 0.13 & 0.14 \\
\hline \hline${ }^{*} \mathrm{p}<0.1,{ }^{* *} \mathrm{p}<0.05,{ }^{* * *} \mathrm{p}<0.01$ & & &
\end{tabular}


C Main model output 
Table A4: Main regression table (Figure 4)

\begin{tabular}{|c|c|c|c|c|}
\hline & Support Abascal (1-10) & & Vote for VOX (0-1) & \\
\hline & Model 1 & Model 2 & Model 3 & Model 4 \\
\hline Treatment & $-0.390^{* * *}$ & $-0.259^{*}$ & $-0.055^{* * *}$ & $-0.035^{* *}$ \\
\hline & $(0.141)$ & $(0.138)$ & $(0.016)$ & $(0.016)$ \\
\hline Sex (male) & & $0.425^{* * *}$ & & $0.055^{* * *}$ \\
\hline & & $(0.075)$ & & $(0.009)$ \\
\hline Age & & $-0.022^{* * *}$ & & $-0.003^{* * *}$ \\
\hline & & $(0.004)$ & & $(0.000)$ \\
\hline Education (other) & & 0.167 & & 0.037 \\
\hline & & $(0.671)$ & & $(0.064)$ \\
\hline Education (primary) & & 0.216 & & 0.004 \\
\hline & & $(0.163)$ & & $(0.018)$ \\
\hline Education (secondary 1) & & 0.101 & & 0.004 \\
\hline & & $(0.126)$ & & $(0.015)$ \\
\hline Education (secondary 2) & & -0.004 & & 0.015 \\
\hline & & $(0.127)$ & & $(0.015)$ \\
\hline Education (none) & & 0.057 & & 0.013 \\
\hline & & $(0.295)$ & & $(0.028)$ \\
\hline Education (further) & & $-0.207^{* *}$ & & -0.013 \\
\hline & & $(0.099)$ & & $(0.012)$ \\
\hline Civil stat (divorced) & & $0.366^{* *}$ & & $0.060^{* * *}$ \\
\hline & & $(0.153)$ & & $(0.018)$ \\
\hline Civil stat (no answer) & & -0.832 & & -0.019 \\
\hline & & $(0.923)$ & & $(0.084)$ \\
\hline Civil stat (separated) & & 0.086 & & 0.001 \\
\hline & & $(0.238)$ & & $(0.028)$ \\
\hline Civil stat (single) & & 0.016 & & -0.018 \\
\hline & & $(0.099)$ & & $(0.011)$ \\
\hline Civil stat (widow(er)) & & -0.101 & & -0.010 \\
\hline & & $(0.173)$ & & $(0.019)$ \\
\hline Employment (unemployed - worked before) & & -0.421 & & 0.027 \\
\hline & & $(0.594)$ & & $(0.069)$ \\
\hline Employment (studying) & & -0.977 & & -0.093 \\
\hline & & $(0.601)$ & & $(0.070)$ \\
\hline Employment (pensioner - worked before) & & -0.263 & & 0.036 \\
\hline & & $(0.605)$ & & $(0.070)$ \\
\hline Employment (other) & & -0.714 & & -0.056 \\
\hline & & $(0.894)$ & & $(0.100)$ \\
\hline Employment (pensioner - didn't work before) & & 0.239 & & 0.105 \\
\hline & & $(0.650)$ & & $(0.075)$ \\
\hline Employment (working) & & -0.586 & & 0.023 \\
\hline & & $(0.586)$ & & $(0.068)$ \\
\hline Employment (unpaid domestic worker) & & -0.204 & & 0.031 \\
\hline & & $(0.626)$ & & $(0.073)$ \\
\hline Employment (no answer). & & & & -0.177 \\
\hline & & & & $(0.210)$ \\
\hline Churchgoer (almost never) & & $-0.609^{* * *}$ & & $-0.054^{* * *}$ \\
\hline & & $(0.166)$ & & $(0.019)$ \\
\hline Churchgoer (almost always) & & $0.564^{* * *}$ & & -0.006 \\
\hline & & $(0.202)$ & & $(0.023)$ \\
\hline Churchgoer (no answer) & & $-1.568^{* *}$ & & $-0.134^{* *}$ \\
\hline & & $(0.630)$ & & $(0.058)$ \\
\hline Churchgoer (none practitioner) & & $-1.265^{* * *}$ & & $-0.106^{* * *}$ \\
\hline & & $(0.165)$ & & $(0.019)$ \\
\hline Churchgoer (multiple times a week) & & $0.698^{* *}$ & & -0.024 \\
\hline & & $(0.314)$ & & $(0.033)$ \\
\hline Churchgoer (multiple times a year) & & -0.260 & & $-0.040^{*}$ \\
\hline & & $(0.187)$ & & $(0.021)$ \\
\hline Constant & $2.347^{* * *}$ & $4.408^{* * *}$ & $0.078^{* * *}$ & $0.258^{* * *}$ \\
\hline & $(0.038)$ & $(0.625)$ & $(0.004)$ & $(0.073)$ \\
\hline Observations & 3483 & 3483 & 3830 & 3830 \\
\hline $\mathrm{R} 2$ & 0.002 & 0.080 & 0.003 & 0.048 \\
\hline R2 Adj. & 0.002 & 0.073 & 0.003 & 0.041 \\
\hline AIC & 16016.5 & 15784.5 & 1336.8 & 1214.7 \\
\hline BIC & 16035.0 & 15963.0 & 1355.5 & 1402.2 \\
\hline Log.Lik. & -8005.242 & -7863.267 & -665.381 & -577.347 \\
\hline $\mathrm{F}$ & 7.671 & 11.175 & 11.924 & 6.829 \\
\hline
\end{tabular}


Table A5: Interaction models (Figure 5)

\begin{tabular}{lcccc}
\hline & Support Abascal (1-10) & & Vote for VOX (0-1) & \\
& Model 1 & Model 2 & Model 3 & Model 4 \\
\hline Treatment & $-0.762^{* * *}$ & $-0.596^{* *}$ & $-0.108^{* * *}$ & $-0.081^{* * *}$ \\
& $(0.261)$ & $(0.259)$ & $(0.029)$ & $(0.028)$ \\
Left-wing voter & $-1.954^{* * *}$ & $-1.757^{* * *}$ & $-0.141^{* * *}$ & $-0.141^{* * *}$ \\
& $(0.075)$ & $(0.078)$ & $(0.009)$ & $(0.009)$ \\
Treatment*Left-wing voter & $0.694^{* *}$ & $0.597^{* *}$ & $0.087^{* *}$ & $0.077^{* *}$ \\
& $(0.300)$ & $(0.296)$ & $(0.034)$ & $(0.034)$ \\
Controls & No & Yes & No & Yes \\
Constant & $3.678^{* * *}$ & $5.184^{* * *}$ & $0.170^{* * *}$ & $0.318^{* * *}$ \\
& $(0.062)$ & $(0.584)$ & $(0.007)$ & $(0.071)$ \\
\hline Observations & 3483 & 3483 & 3830 & 3830 \\
R2 & 0.167 & 0.201 & 0.065 & 0.104 \\
R2 Adj. & 0.167 & 0.194 & 0.064 & 0.097 \\
AIC & 15390.4 & 15298.1 & 1094.7 & 987.8 \\
BIC & 15421.2 & 15488.9 & 1125.9 & 1187.8 \\
Log.Lik. & -7690.210 & -7618.046 & -542.337 & -461.909 \\
F & 233.014 & 29.975 & 88.870 & 14.635 \\
\hline${ }^{*} \mathrm{p}<0.1{ }^{* *} \mathrm{p}<0.05,{ }^{* * *} \mathrm{p}<0.01$ & & & &
\end{tabular}


Table A6: Region FE models

\begin{tabular}{lcccccc}
\hline & \multicolumn{3}{c}{ Support Abascal (1-10) } & & \multicolumn{3}{c}{ Vote for VOX (0-1) } \\
& Model 1 & Model 2 & Model 3 & Model 4 & Model 5 & Model 6 \\
\hline Treatment & $-0.390^{* * *}$ & $-0.259^{*}$ & $-0.264^{*}$ & $-0.055^{* * *}$ & $-0.035^{* *}$ & $-0.027^{*}$ \\
& $(0.141)$ & $(0.138)$ & $(0.141)$ & $(0.016)$ & $(0.016)$ & $(0.016)$ \\
Controls & No & Yes & Yes & No & Yes & Yes \\
Regional FE & No & No & Yes & No & No & Yes \\
Constant & $2.347^{* * *}$ & $4.408^{* * *}$ & $4.450^{* * *}$ & $0.078^{* * *}$ & $0.258^{* * *}$ & $0.166^{*}$ \\
& $(0.038)$ & $(0.625)$ & $(0.840)$ & $(0.004)$ & $(0.073)$ & $(0.097)$ \\
\hline Observations & 3483 & 3483 & 3483 & 3830 & 3830 & 3830 \\
R2 & 0.002 & 0.080 & 0.100 & 0.003 & 0.048 & 0.080 \\
R2 Adj. & 0.002 & 0.073 & 0.076 & 0.003 & 0.041 & 0.058 \\
AIC & 16016.5 & 15784.5 & 15834.3 & 1336.8 & 1214.7 & 1209.7 \\
BIC & 16035.0 & 15963.0 & 16400.6 & 1355.5 & 1402.2 & 1791.0 \\
Log.Lik. & -8005.242 & -7863.267 & -7825.132 & -665.381 & -577.347 & -511.856 \\
$\mathrm{~F}$ & 7.671 & 11.175 & 4.199 & 11.924 & 6.829 & 3.567 \\
\hline${ }^{*} \mathrm{p}<0.1,{ }^{* *} \mathrm{p}<0.05,{ }^{* * *} \mathrm{p}<0.01$ & & & & &
\end{tabular}


Table A7: Placebo models: support for PP

\begin{tabular}{|c|c|c|c|c|}
\hline & Support Casado (1-10) & & Vote for PP (0-1) & \\
\hline & Model 1 & Model 2 & Model 3 & Model 4 \\
\hline Treatment & $\begin{array}{l}-0.105 \\
(0.130)\end{array}$ & $\begin{array}{c}-0.132 \\
(0.126)\end{array}$ & $\begin{array}{l}-0.027 \\
(0.018)\end{array}$ & $\begin{array}{l}-0.023 \\
(0.018)\end{array}$ \\
\hline Controls & No & Yes & No & Yes \\
\hline Constant & $\begin{array}{c}3.440^{* * * *} \\
(0.036)\end{array}$ & $\begin{array}{c}4.597^{* * *} \\
(0.577)\end{array}$ & $\begin{array}{c}0.099^{* * * *} \\
(0.005)\end{array}$ & $\begin{array}{l}0.161^{* *} \\
(0.081)\end{array}$ \\
\hline Observations & 3548 & 3548 & 3830 & 3830 \\
\hline R2 & 0.000 & 0.098 & 0.001 & 0.066 \\
\hline R2 Adj. & 0.000 & 0.090 & 0.000 & 0.059 \\
\hline AIC & 15851.8 & 15541.8 & 2288.9 & 2085.4 \\
\hline $\mathrm{BIC}$ & 15870.3 & 15727.0 & 2307.7 & 2272.9 \\
\hline Log.Lik. & -7922.903 & -7740.892 & -1141.463 & -1012.686 \\
\hline $\mathrm{F}$ & 0.648 & 13.605 & 2.330 & 9.531 \\
\hline
\end{tabular}


Table A8: Interaction models with PP placebo (Figure 6)

\begin{tabular}{lcccc}
\hline & $\begin{array}{c}\text { Support Casado (1-10) } \\
\text { Model 1 }\end{array}$ & Model 2 & Vote for PP (0-1) \\
& 0.321 & 0.283 & 0.003 & 0.010 \\
Treatment & $(0.250)$ & $(0.244)$ & $(0.033)$ & $(0.032)$ \\
& $-1.039^{* * *}$ & $-0.733^{* * *}$ & $-0.139^{* * *}$ & $-0.112^{* * *}$ \\
Left-wing voter & $(0.074)$ & $(0.075)$ & $(0.010)$ & $(0.011)$ \\
& -0.469 & $-0.492^{*}$ & -0.029 & -0.035 \\
Treatment*Left-wing voter & $(0.289)$ & $(0.281)$ & $(0.039)$ & $(0.038)$ \\
& No & Yes & No & Yes \\
Controls & $4.145^{* * *}$ & $4.909^{* * *}$ & $0.189^{* * *}$ & $0.206^{* *}$ \\
Constant & $(0.061)$ & $(0.569)$ & $(0.008)$ & $(0.080)$ \\
\hline Observations & 3548 & 3548 & 3830 & 3830 \\
R2 & 0.060 & 0.126 & 0.052 & 0.096 \\
R2 Adj. & 0.059 & 0.118 & 0.052 & 0.089 \\
AIC & 15637.0 & 15433.8 & 2089.3 & 1962.8 \\
BIC & 15667.8 & 15631.3 & 2120.5 & 2162.9 \\
Log.Lik. & -7813.484 & -7684.881 & -1039.635 & -949.417 \\
F & 75.388 & 16.858 & 70.468 & 13.443 \\
\hline${ }^{*} P<0.1^{* *}{ }^{*}<0.05^{* * *} p<0.01$ & & &
\end{tabular}




\section{Nearest Neighbour Matching}

\section{NNM matching models}

Upper panel: Full sample | Lower panel: Right-wing voters

Support for Abascal

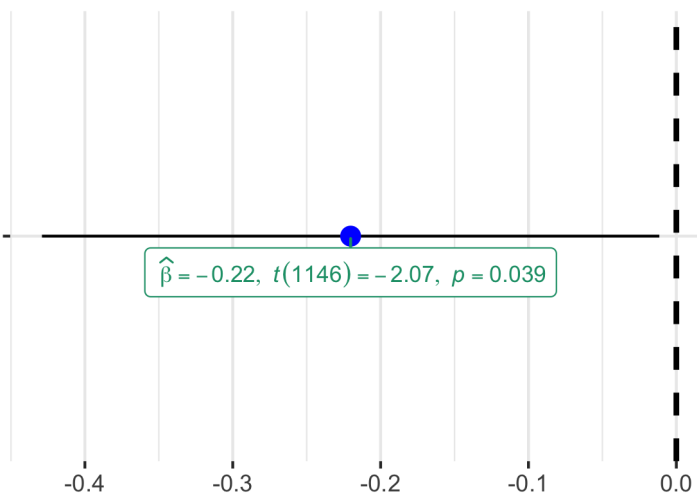

$\mathrm{AIC}=4645, \mathrm{BIC}=4660$

Support for Abascal

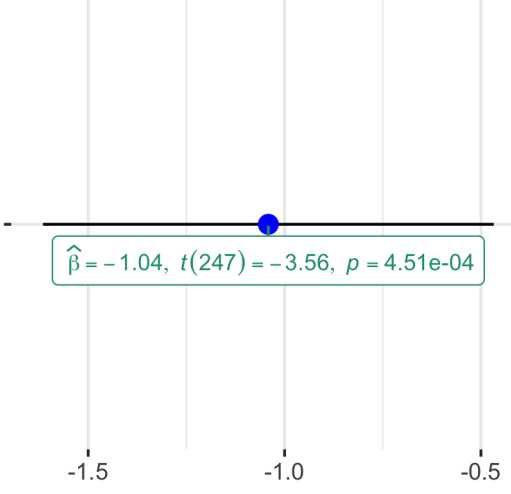

Voting for VOX

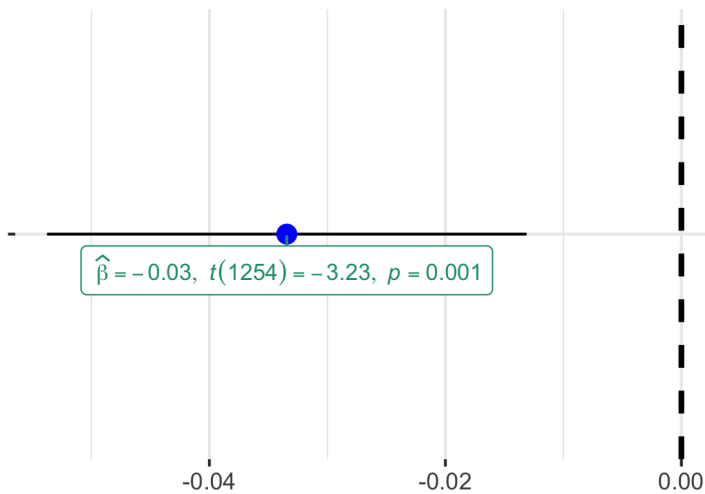

$A I C=-667, B I C=-652$

\section{Voting for VOX}

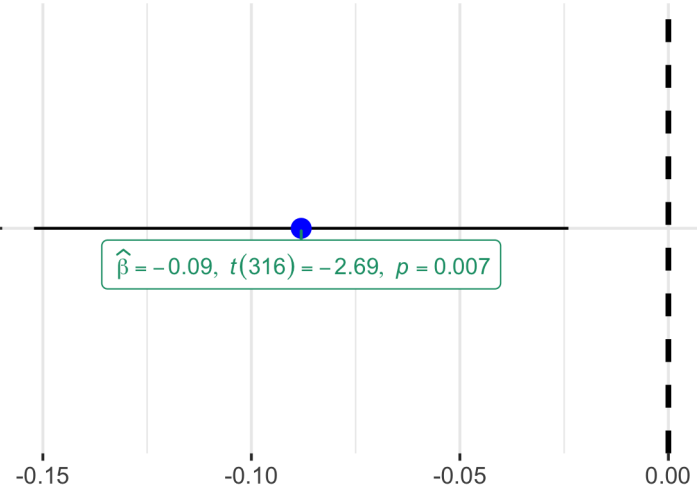

$\mathrm{AIC}=1131, \mathrm{BIC}=1142$

$A I C=119, B I C=130$

Figure A2: Estimated effects using NNM

In Figure A2 we present results from near-neighbour matching (NNM). NNM matches similar individuals from the treatment and control groups, which we have matched on our covariates: gender, age, education, civil status, religiosity and left-right ideological placement. This serves the purpose of providing an additional robustness test against the possibility that our pre- and post-treatment samples differ in substantive ways. We carry out the matching approach using the full sample as well as the subsample of voters who identify on the right given the heterogeneous treatment effects we observe. The success of the matching protocol is visualised in Figure A3 for the full sample and Figure A4 for the right-wing subsample. 
The results of our models relying on NNM confirm the empirical results presented in the main text. Whilst in the case of the full sample, the NNM point-estimates are slightly smaller they still follow the same direction and significance of the full sample models reported in Table A4. Note, however, that the NNM point-estimates for the right-wing voter sample is slightly larger. We interpret the out of this additional modelling strategy as additional evidence in support of our main conclusions.

\section{Distribution of Propensity Scores}

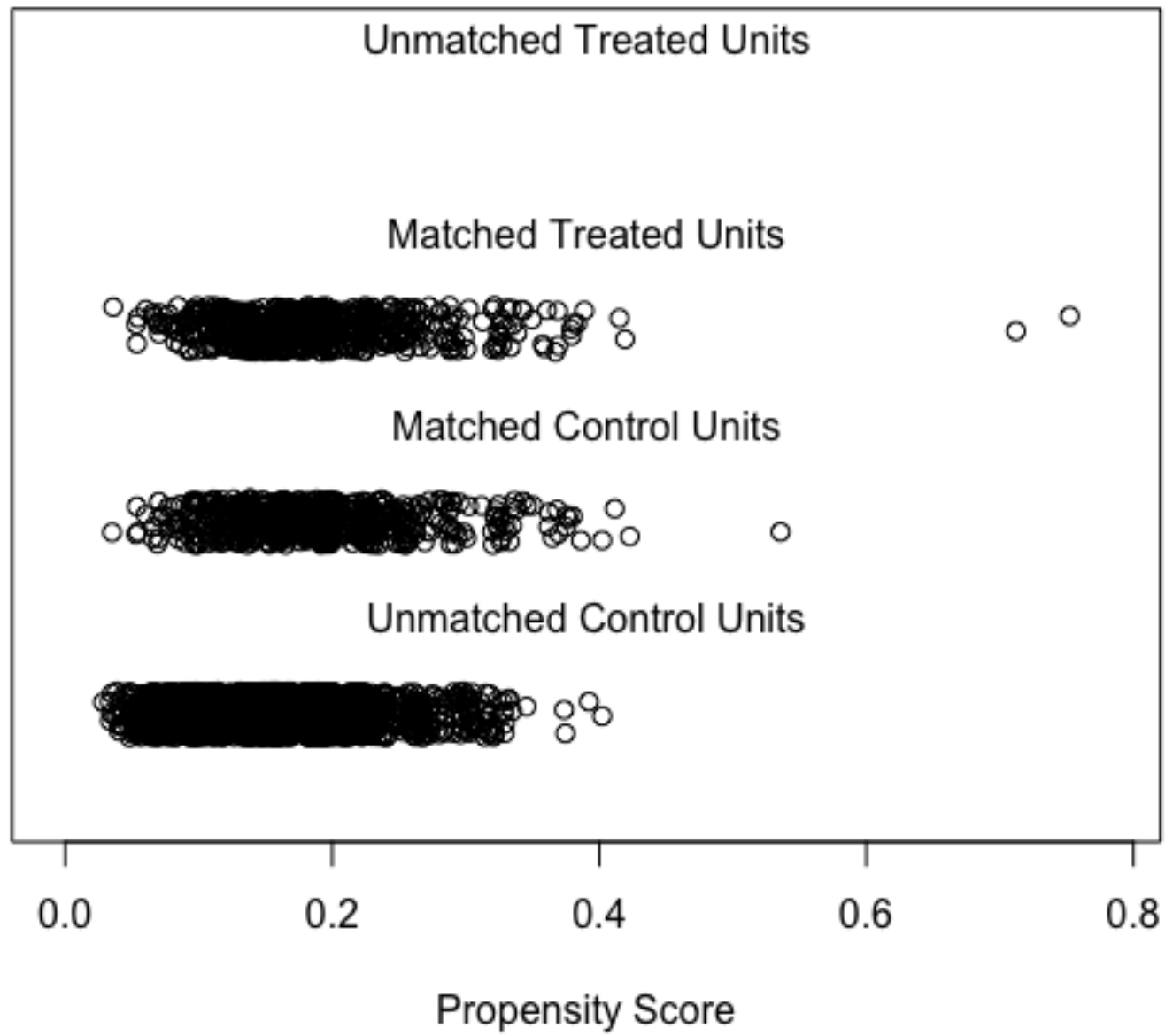

Figure A3: Matching outcomes: Full sample 


\section{Distribution of Propensity Scores}

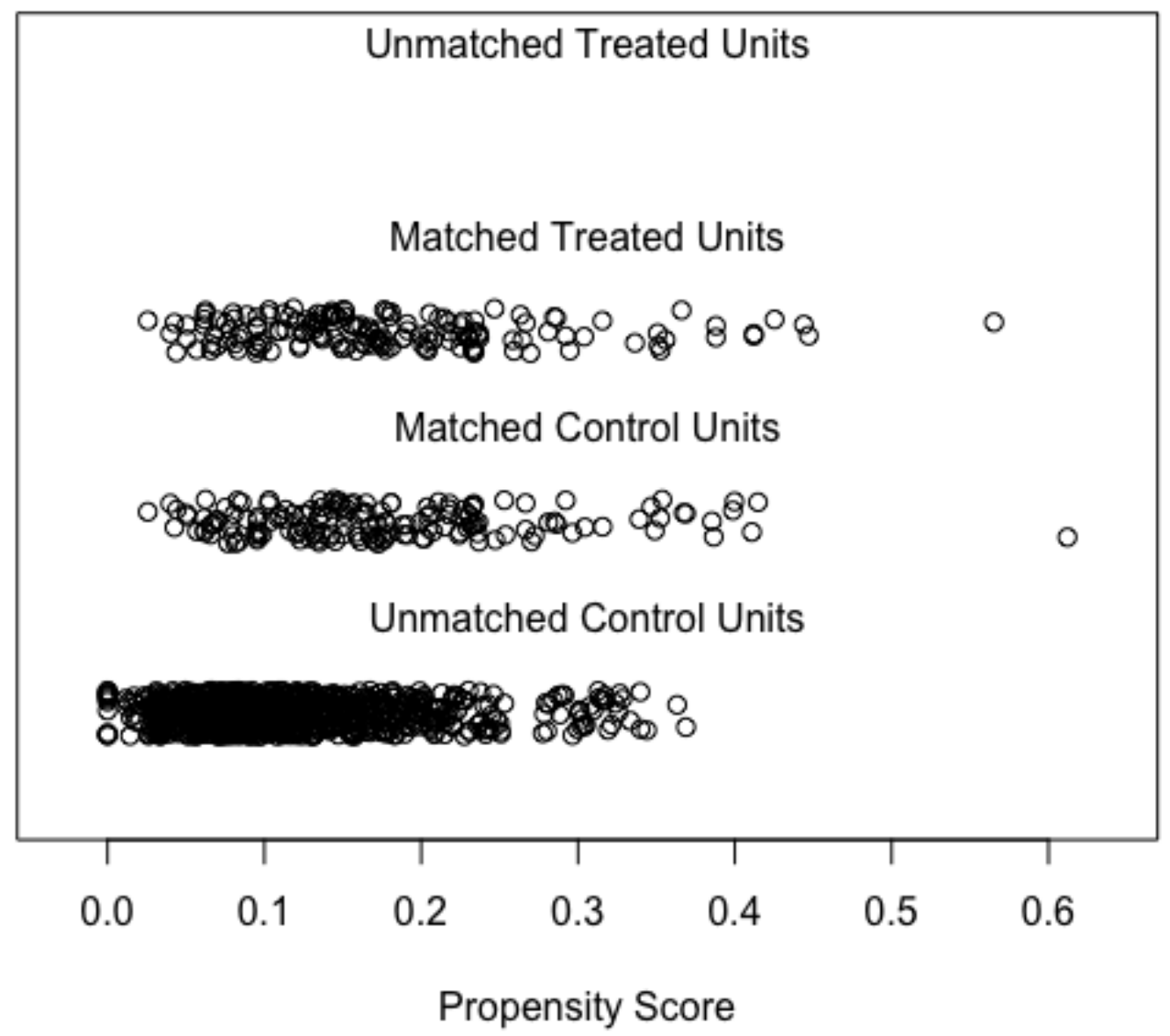

Figure A4: Matching outcomes: Right-wing subsample 


\section{E RDD model output}

Table A9: RDD model estimates

\begin{tabular}{lcccc}
\hline & $\begin{array}{c}\text { Support for Abascal } \\
\text { Local linear }\end{array}$ & 4th order polynomial & $\begin{array}{c}\text { Voting intentions } \\
\text { Local linear }\end{array}$ & 4th order polynomial \\
\hline Discontinuity estimate & $-0.49^{* *}$ & $-0.45^{* * *}$ & -0.03 & $-0.04^{* *}$ \\
& $(0.24)$ & $(0.17)$ & $(0.03)$ & $(0.02)$
\end{tabular}

Standard errors in parentheses

${ }^{* * *} \mathrm{p}<0.01,{ }^{* *} \mathrm{p}<0.05,{ }^{*} \mathrm{p}<0.1$ 